\title{
Reinvestigation of African Surirella taxa (Bacillariophyta) described by B.J. Cholnoky with some remarks on digitization of diatom types
}

\author{
Christine CocquYT ${ }^{1}$, Jonathan C. TAYLOR ${ }^{2,3}$ \& Wolf-Henning KuSBER ${ }^{4}$
}

\author{
${ }^{I}$ Botanic Garden Meise, Nieuwelaan 38, B-1860 Meise, Belgium; \\ Corresponding author e-mail: christine.cocquyt@botanicgardenmeise.be \\ ${ }^{2}$ School of Biological Sciences, North-West University, Potchefstroom, South Africa \\ ${ }^{3}$ South African Institute for Aquatic Biodiversity (SAIAB), Grahamstown, South Africa \\ ${ }^{4}$ Botanischer Garten und Botanisches Museum Berlin-Dahlem (BGBM), Freie Universität Berlin, Königin- \\ Luise-Str. 6-8, D-14195 Berlin, Germany
}

\begin{abstract}
Cholnoky described several new Surirella taxa from Africa and we have re-investigated this material. As many other of his contemporary authors, especially in the case of description of new African diatoms, Cholnoky did not indicate holotypes. In the present paper original materials are re-evaluated, lectotypes and a holotype are designated and also epitypes whenever it was appropriate. Taxa later transferred to Stenopterobia have not been taken into account. A short description of the seven species concerned (Surirella anassae, $S$. chasei, S. coei, S. oliffii, S. ostentata = Surirella ovata var. africana, S. pseudotenuis and S. pseudothienemannii) is given based on the original light microscopic descriptions. Additional morphological information based on scanning electron microscopy is added if available. The presently known ecology and distribution of the taxa is given as are other remarks, based on own observations. For each of the seven taxa Cholnoky's original drawings are presented, which were later re-drawn for publication and which are kept in the archive of the South African National Diatom Collection. The results are discussed referring to the outcome of the digitization project of African Surirellaceae (diatoms, microscopic algae) in the frame of the African Plants Initiative.
\end{abstract}

Key words: Cholnoky, South Africa, Surirella, taxonomy, types, African Plants Initiative

\section{INTRODUCTION}

A re-investigation of material used by Cholnoky to describe several Surirella TURPIN taxa from Africa (CHOLNOKY 1954, 1955, 1957, 1958, 1959, 1960a, 1960b, 1960c, 1962) was conducted. The study of Cholnoky's Surirellaceae resulted from a digitization project of African Surirellaceae types for Aluka, an international collaborative initiative tasked with building an online digital library of scholarly resources about Africa. In 2008 Aluka became part of JSTOR which merged with Ithaka in 2009 (www.JSTOR.org). The digitization project of African Surirellaceae included among others taxa described from Central and East Africa by Müller (Müller 1903, 1904, 1905, 1910; CoCQuYT 2000; CocQuYT \& JAHN 2005a, 2007a, b, c, d; CoCQuYT et al. 2007) and by Hustedt (Hustedt in Huber-PesTALOZZI 1942), from West Africa by Foged (Foged 1966; CocQuYT \& KusBer 2010) and by Woodhead \& Tweed (Woodhead \& Tweed 1958, 1960; CocQuyT et al. 2013). Cholnoky, as many other authors in the past (e.g., Woodhead \& TweEd 1958, 1960), did not indicate holotypes. Therefore we designate lectotypes in the present paper and, when preparations within the original material are absent, epitypes.

Within the genus Surirella, Cholnoky described thirteen species, two varieties and two forms; within the genus Stenopterobia BréBISSON ex VAN Heurck only one species and a form. The present paper only deals with the Surirella species; the Stenopterobia species and the taxa belonging to the genus Surirella, which are already or not transferred, e.g. Surirella schweickerdtii CHOLNOKY (BRASSAC et al. 2003) will not be discussed here. Two Surirella taxa described by Cholnoky, S. deliciosa Cholnoky and S. gieskesii Cholnoky (Cholnoky 1963), were not from Africa but from New Guinea (Asia) and are not taken into account in the present paper which only deals with African material. It is worth noting that Cholnoky made his original drawings on paper with large squares, with each quandrant corresponding to a square of $5 \times 5 \mu \mathrm{m}$. These original drawings, kept at the South African National Diatom Collection, were scanned and reproduced here for all the considered taxa. 


\section{Material And Methods}

Original slides of the material from which Cholnoky described thirteen Surirella species, two varieties and two forms, held in the South African National Diatom Collection (housed at the North West University, Potchefstroom, South Africa) were studied. The investigation was done both at the North-West University, South Africa, and at the Botanic Garden Meise, Belgium. In South Africa microscopy was done using a Nikon Eclipse 80i, in Belgium using an Olympus BX51. Both microscopes were equipped with Differential Interference Contrast and digital cameras, a Nikon DSU2 and an Olympus ColorView III digital camera respectively. Small parts of raw material, available in the South African National Diatom Collection were cleaned with peroxide, rinsed with distilled water. Aliquots of the cleaned material were put and aluminium stubs, air dried and sputter-coated with gold palladium for scanning electron microscopy (SEM). SEM was done at the North West University, South Africa with a FEI Quanta 339 operating at $10 \mathrm{KV}$. SEM stubs are deposited in the South African National Diatom Collection, housed at the North-West University, Potchefstroom, South Africa.

The following slides were examined:

NIWR 169/3367, collector number: S.W. Africa 164; South West Africa (now Namibia) collected by Cholnoky in Okawango, Tscheye on 10 August 1962. Preparation made on 26 November 1962.

NIWR 186/3707, collector number: Tugela 70; Natal (now Kwa-Zulu Natal), Nkunzini River between Tugela Village and Stanger, under the bridge of the Zululand road, Kwa-Zulu Natal, South Africa, collected by Cholnoky on 16 July 1954.

NIWR 186/3708, collector number: Tugela 70; Natal (now Kwa-Zulu Natal), Nkunzini River between Tugela Village and Stanger, under the bridge of the Zululand road, Kwa-Zulu Natal, South Africa, collected by Cholnoky on 16 July 1954.

NIWR 191/3802, collector number: Tugela 217; Usutu River (now Maputo River) below the bridge on the road to Golela, Swaziland, collected by Cholnoky on 18 July 1957.

NIWR 193/3860, collector number: Tugela 285; Natal (now Kwa-Zulu Natal), Umhlalzi River between Eshowe and Melmoth, South Africa, collected by Cholnoky on 27 July 1957. Preparation made on 15 January 1959.

NIWR 194/3873, collector number: Tugela 298; Natal (now Kwa-Zulu Natal), Goedgegun (now Nhlangano) near Pongola, South Africa, collected by Cholnoky on 28 July 1957. Preparation made on 13 January 1959.

NIWR 197/3936, collector number: Tugela 362; Natal (now Kwa-Zulu Natal), Durban-Amanzimtoti: small tributary of the Umzimkulwana River near to the Paddock entrance to Oribi Gorge, South Africa, collected by Cholnoky on 22 July 1958. Preparation made on 22 December 1958.

NIWR 206/4103, collector number E.T. 29; Eastern Transvaal (now Mpumalanga), tributary of the Elands River between Belfast and Machadodorp, South Africa, collected by J. Agnew on 23 August 1960. Preparation made on 2 September 1960.

NIWR 236/4716, collector number dHFR 4; Northern Transvaal (now Limpopo Province), De Hoek nature reserve: trickling stream, shallow, Debegeni, South Africa, collected by H.G. Schweickerdt in December 1953.
NIWR 332/6627, collector number Kenya "A"; Hall Tarn at $4358 \mathrm{~m}$ asl in the Gorges Valley, Mount Kenya; Kenya, collected by M.J. Coe, date unknown.

NIWR 241/4812, collector number SWAZI 15; unnamed mountain stream between Piggs Peak and Mbabane, Swaziland, collected by H. Welsh on 3 July 1960. Preparation made on 24 July 1961.

NIWR 297/4937, collector number B 1(9555); Region of Bangweolo Lake, $10 \mathrm{~km}$ from Kansengs, Chali Lake, collected by J.-J. Symoens on 5 June 1962.

NIWR 252/5039, collector number N 118; Eastern Transvaal (now Mpumalanga), Modderpoort 2, between Warmbaths (now Bela Bela) and Nylstroom (now Modimole); stream under roadway bridge (part of the channel of the Nylstroom River) alongside fast flowing water, South Africa, collected by G. Moerdijk on 6 June 1954.

NWU 07-138, collector number C5; Gully, south of the road to Vumba, Umtali, South Rhodesia, now Zimbabwe, collected by N.C. Chase on 17 July 1952.

NWU 07-172, collector number C4; Eastlands, Umtali District, South Rhodesia now Zimbabwe. Streambank fully exposed to sunlight, source of mountain ravine on a fern hill on the borders of the Eastlands, collected by N.C. Chase on 10 August 1952.

JO 8, canal near Vredendal, splitting of the Olifantsrivier in the mountains, Western Cape, South Africa, collected by A.H.P. Engelbrecht on July 1953.

\section{Results}

\section{Surirella anassae CHOLnOKy (Figs 1-8),}

Österreichische botanische Zeitschrift 104: 84, figs 278-279, 1957.

Light microscopy (Figs 1-6): Valve heteropolar, elongate ovate with broadly rounded apical pole and a sub-acutely rounded base pole, 60.0-95.0 $\mu \mathrm{m}$ long and 38.0-48.0 $\mu \mathrm{m}$ wide; length to width ratio: $1.8-2.0$. Broadest part of the valve located between $1 / 4$ and $1 / 2$ of the valve face towards the apical pole. Valve face appears flat in LM, apical and base pole not in the same plane but bent towards the girdle, the head pole much more strongly bent than the foot pole. Wing projection not very distinct but most obviously pronounced near the head pole. Alar canals 2.0 in $10 \mu \mathrm{m}$, becoming denser near the base pole to about 3.5 in $10 \mu \mathrm{m}$. Alae poorly developed and only visible on the valve face near the margin. Broad alar canals divided into 1-2 canaliculi, except near the base pole where the alar canals have only one canalicilus. Space between two alar canals about 3.0-4.0 $\mu \mathrm{m}$. Striation parallel mid-valve becoming radiate towards the poles. About 25-26 striae in $10 \mu \mathrm{m}$. Axial area narrow, elliptical.

Scanning electron microscopy (Figs 7-8): Valve face undulate, transapical valve undulations (porcae) shallow and reaching the middle of the valve which is elevated. At the end of this elevation the valve face is indented to both sides. Near the apical pole the valve 


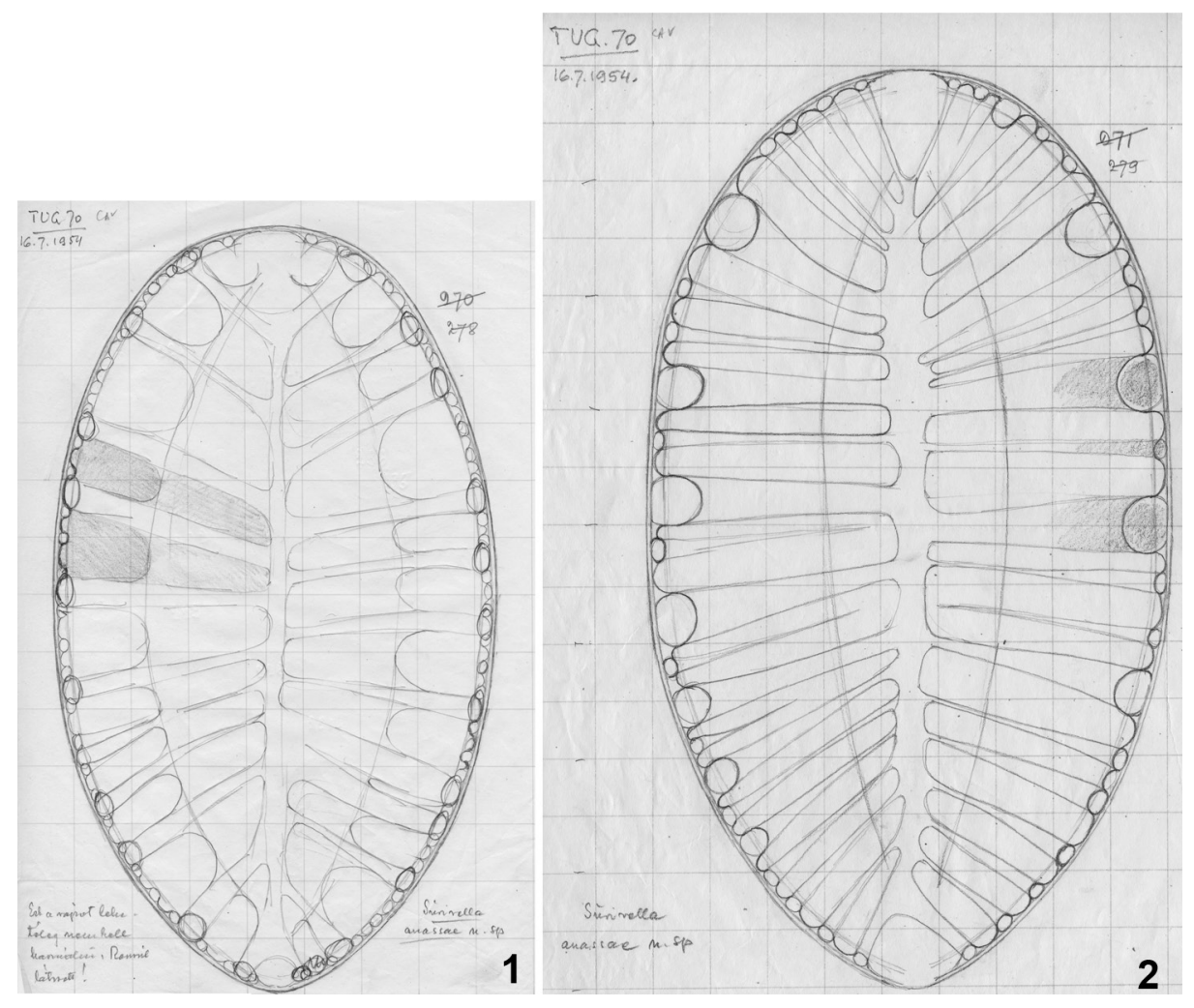

Figs 1-2. Surirella anassae, original drawings by Cholnoky, kept at the South African National Diatom Collection, housed at the North-West University, South Africa. Each quadrant corresponds with a square of $5 \times 5 \mu \mathrm{m}$. face raises again originating in an undulation perpendicular to the porcae (Fig. 7). Four longitudinal lines, parallel to and on each side of the axial area (Fig. 8) are present extending from the head pole towards the foot pole. The longitudinal line close to the axial area is less distinct than the other three lines. No spines present on the valve. Striae uniseriate near the middle, becoming quickly bi- to triseriate towards the valve margin, composed of about 100 areolae in $10 \mu \mathrm{m}$. Striae continuous in the middle, no hyaline axial area present. Striae on the mantle dense, around 70 in $10 \mu \mathrm{m}$. Fenestra much smaller than the alar canals, 5-7 fenestral fibulae present per fenestra. Canaliculi seem to be subdivided by canaliculi of the second order (Fig. 7), with the result that there can be 5 canaliculi in total in an alar canal which is in contrast to the LM observations where only 1-2 canaliculi were observed. Raphe canal smooth. Girdle bands not observed.

Lectotype (designated here): Slide NIWR 186/3707 (the valve representing the lectotype is here illustrated as Figs. 3, 4), South African National Diatom Collection, housed at the North-West University, South Africa.

Type locality: Tugela Village, Nkunzini (Kwa-Zulu Natal, South Africa), Nkunzini River between Tugela Village and Stanger (halfway the bridge of the Zululand-mainstreet).

Ecology: Epiphytic on aquatic plants in neutral to slightly alkaline rivers. In the type locality the taxon was found epiphytic on a Spirogyra filamentous mass; the $\mathrm{pH}$ measured colorimetrically was 7.6.

Distribution: This taxon is reported from South Africa (CHolnoky 1957) and Ghana (Foged 1966). However, the data in the literature have to be carefully checked as closely related taxa such as $S$. capensis are easily misidentified as Surirella anassae, even in reports from South Africa. Foged (1966) reported S. anassae from Ghana in small rivers located in macro-vegetation area of coastal shrubs, coastal zone and semi-deciduous forest.

Remarks: This taxon is closely related to $S$. capensis Ehrenberg ex Cocquyt et R. JAHN (COCQUYT \& JAHN $2005 \mathrm{~b}$ ). The valve outline is the most distinguishing characteristic between the two taxa with the broadest part of the valve located at a different position with regard to the apical pole. Beside the fact that the alar canals of $S$. anassae are broader than in the closely related $S$. sparsipunctata Hustedt (COCQUYT \& VyVERMAN 1993), described from Lake Tanganyika, this taxon differs distinctly by possessing fenestrae and fenestral bars, which are totally absent in S. sparsipunctata. Surirella capensis is found only on the mica type slide of Ehrenberg with no other material available, thus the presence or absence of fenestrae and fenestral bars could not be observed in this taxon. The ecology of $S$. anassae also differs from $S$. sparsipunctata: epiphytic in slightly alkaline rivers versus benthic in a large alkaline lake. 

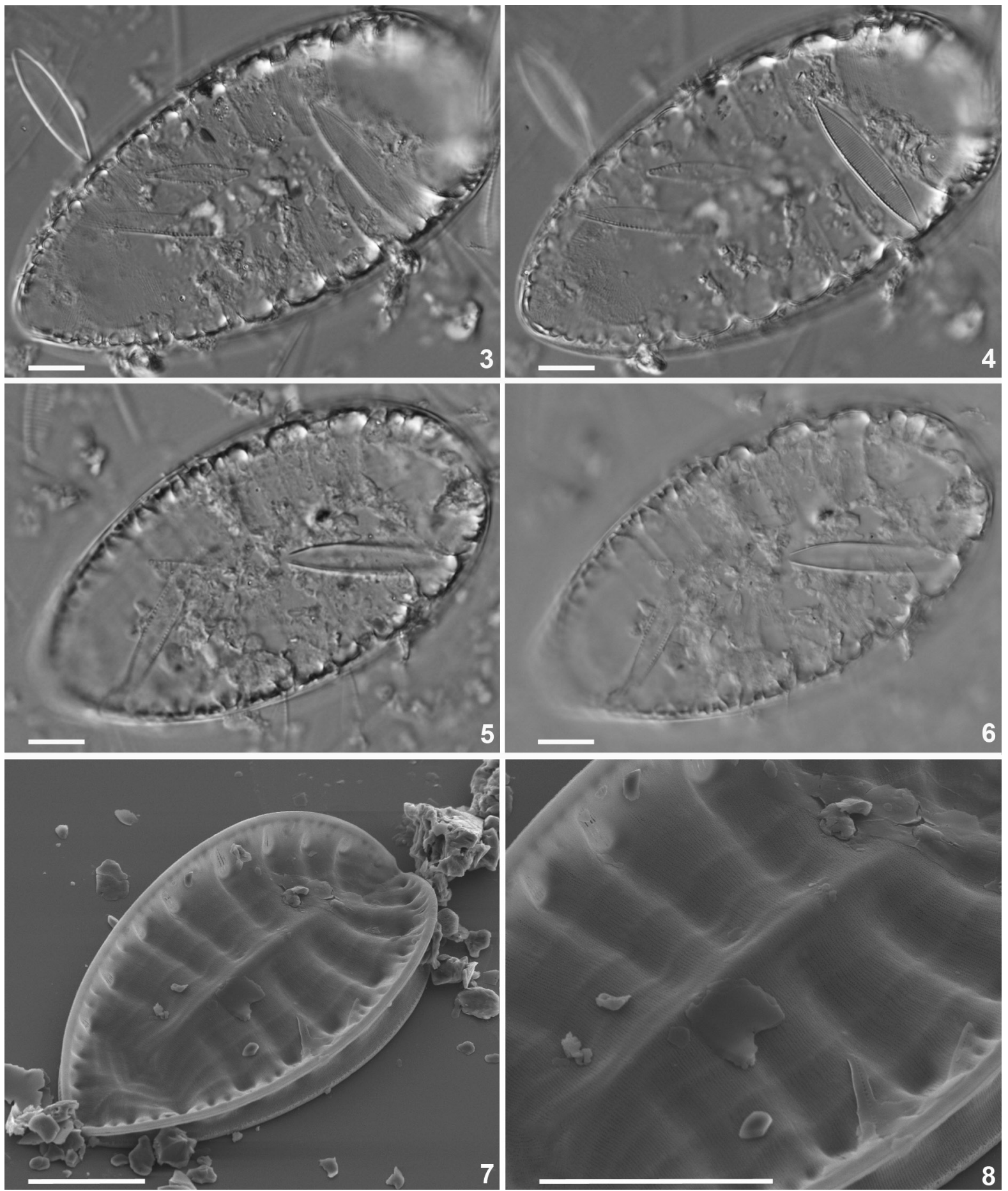

Figs 3-8. Surirella anassae: (3-4) LM, valve from lectotype slide NIWR 186/3707, taken at different foci; (5-6) LM, valve from slide NIWR 186/3708 taken at different foci; (7-8) SEM, type material from sample Tugela 70, (7) exterior view of valve showing the wings, the fenestrae with fenestral bars, the transapical valve undulations and the canaliculi appearing like to be subdivided by canaliculi of the second order (arrow), (8) detail of the fenestrae with fenestral bars and the four longitudinal lines (arrows) parallel to and on each side of the axial area. Scale bar $10 \mu \mathrm{m}$.

\section{Surirella chasei Cноцnоку (Figs 9-29),}

Portugaliae Acta Biologica ser. B 4: 225, figs 118-119, 1954.

Light microscopy (Figs 9-17): Valve distinct heteropolar, become less heteropolar in the smaller valves, with evenly ovate-elliptical rounded poles, length:
35.0-78.9 $\mu \mathrm{m}$, width: $17.0-33.3 \mu \mathrm{m}$, length to width ratio: $1.9-2.5$. Wing projection distinct; $35-45$, mostly 40 alar canals in $100 \mu \mathrm{m}$. About 13-14 striae in $10 \mu \mathrm{m}$. Valve face ornamented with small refracting granules located at the rim of the alar canals on the top of the porcae and irregularly scattered on the valve face in between the porcae. 
Table 1. Overview of different morphological features in S. oliffii, based on Cholnoky's original drawings kept at South African National Diatom Collection, North-West University, South Africa and here represented in Figures 40-43.

\begin{tabular}{|c|c|c|c|c|}
\hline & Fig. 40 & Fig. 41 & Fig. 42 & Fig. 43 \\
\hline Length $(\mu \mathrm{m})$ & 91.0 & 103.0 & 93.0 & 93.0 \\
\hline \multirow{3}{*}{$\begin{array}{l}\text { Width }(\mu \mathrm{m}) \text { near apical pole } \\
\text { near foot pole } \\
\text { constricted middle }\end{array}$} & 27.0 & 27.5 & 30.0 & 29.0 \\
\hline & 24.0 & 25.5 & 29.0 & 29.0 \\
\hline & 23.0 & 24.0 & 27.5 & 29.0 \\
\hline \multirow[t]{3}{*}{ Length-to-width ratio } & 3.4 & 3.7 & 3.1 & 3.2 \\
\hline & 3.8 & 4.0 & 3.2 & 3.2 \\
\hline & 4.0 & 4.3 & 3.4 & 3.2 \\
\hline Apical pole & $\begin{array}{l}\text { broadly rounded } \\
\text { and slightly acute }\end{array}$ & broadly rounded & broadly rounded & $\begin{array}{l}\text { broadly rounded } \\
\text { but less than the } \\
\text { others }\end{array}$ \\
\hline Foot pole & broadly rounded & broadly rounded & broadly rounded & broadly rounded \\
\hline Alar canals/100 $\mu \mathrm{m}$ & 20 & 19 & 17 & 20 \\
\hline Alar canals mid-valve & almost parallel & almost parallel & almost parallel & parallel \\
\hline apical pole & radiate & radiate & radiate & radiate \\
\hline foot pole & radiate & radiate & radiate & radiate \\
\hline Striae & visible & visible & invisible & invisible \\
\hline Fenestrae/alar canals & broader & broader & much broader & slightly broader \\
\hline Fenestrae width $(\mu \mathrm{m})$ mid-valve & $2.0-5.0$ & $2.0-3.5$ & $4.0-6.0$ & $3.0-4.0$ \\
\hline \multirow[t]{2}{*}{ Axial area } & linear & linear & linear & linear \\
\hline & rarrow & very narrow & very narrow & very narrow \\
\hline Spines & absent & absent & absent & present \\
\hline
\end{tabular}

Scanning electron microscopy (Figs 18-29): Porcae not reaching the very narrow axial area, except close to the base pole. Mid-region of the valve slightly undulate (Fig. 18). Small blunt teeth present near the apical pole at the junction of the valve face and the valve mantle (Figs 20, 27, 28). This row of blunt teeth continues at the edge of the valve mantle but are located in the indented part of the mantle (Figs 20, 28). Striae uniseriate near the axial area and composed of 56 round areolae in $10 \mu \mathrm{m}$, becoming biseriate towards the valve margin. Valve face plentifully ornamented, ranging from valves with scattered granules (Figs 24-25) to more complex structures with small granules and blunt cones/spines near the axial area and in the shallow parts of the porcae (Figs 23, 26), while on the top and on both sides of the porcae there are larger and more complex silica structure present, from bone-like (Figs 18-21) to ramificated with short branches (as is a Baobab tree) (Fig. 26) to flower-like in top view (Fig. 23). Wings vertically developed from the valve face and with a reduction in height near the apices where they are interrupted, leaving a broad space near the head pole and a narrow space near the foot pole. Fenestrae more or less rectangular and wider than the alar canals with 4-6, exceptionally 2 , fenestral bars in each fenestra. The complex silica structures present on the valve face are also present on the alar canals adjacent to the fenestrae. Raphe canal smooth; raphe endings straight and slightly enlarged at both poles. Valve mantle indented, striae uniseriate near the mantle edge and becoming biseriate towards the fenestrae. Silica granules or more complex silica structures present on the mantle in accordance with the structures on the valve face.

Internally the uniseriate striae become biseriate towards the valve margin and again uniseriate on the mantle close to its outer margin (Figs 27-29). Portula round, the striae entering the portulae are bi- to triseriate (Figs 27-29).

Lectotype (designated here): Slide NWU 07-172, from material $\mathrm{C} 4$ (the valve representing the lectotype is here illustrated as Fig. 14), South African National Diatom Collection, housed at the North-West University, South Africa.

Type locality: Eastlands, Umtali District, Southern Rhodesia (now Zimbabwe). Stream bank fully exposed to sunlight, source of mountain ravine on a fern hill on border of Eastlands.

Ecology: Periphytic and epiphytic on mosses in streams, prefers alkaline and probably rather mesotrophic water. 


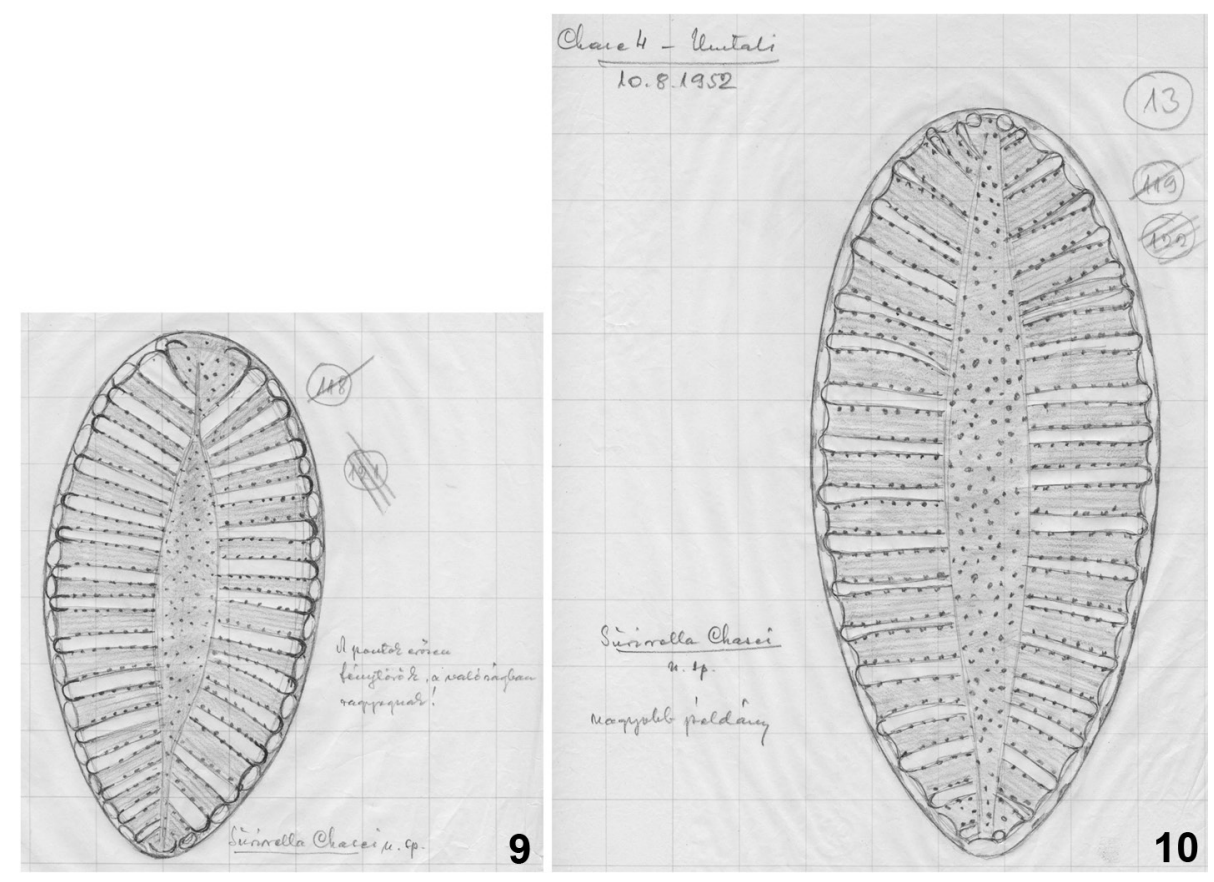

Figs 9-10. Surirella chasei, original drawings by Cholnoky, kept at the South African National Diatom Collection, housed at the North-West University, South Africa. Each quadrant corresponds with a square of $5 \times 5 \mu \mathrm{m}$.
Distribution: South Africa, Zimbabwe, Lesotho.

Remarks: This taxon is closely related to Surirella rudis Hustedt, a species described from Lake Tanganyika (Hustedt in Schmidt 1922, T. 356, figs 5-6). Surirella rudis differs in its valve shape which is obviously heteropolar with a broadly rounded apical and sharply rounded base pole. Moreover $S$. rudis can become lar-ger, with a length of 60 to $112 \mu \mathrm{m}$ (HusteDT in Huber-Pestalozzi 1942; Cocquyt 1998). In the last mentioned publication $S$. rudis was wrongly put in synonymy with Surirella terryi WARD ex TERRY (VESELÁ et al. 2013). The number of alar canals in $100 \mu \mathrm{m}$ also differs: $35-45$ in S. chasei and 16-20 in S. rudis. No SEM images are available of $S$. rudis, so no comparison can be made on the structure of the granules, which are star shaped in S. chasei. The ecology of both species is also different: periphytic and epiphytic on mosses in streams with are probably rather mesotrophic compared to oligotrophic large lakes (HUSTEDT in Huber-Pestalozzi 1942).

\section{Surirella coei Cholnoky ex Cocquyt, J.C. TAYlor et} KusBer, sp. nov. (Figs 30-39)

Surirella coei CHOLNOKY, Österreichische botanische Zeitschrift 107: 362, figs 25-26, 1960, nom. inval. (Art. 40.1, McNeill et al. 2012).

Light microscopy (Figs 30-35): Valves isopolar with broadly rounded ends, linear and constricted midvalve; length: $31.8-75.0 \mu \mathrm{m}$, width: $8.0-14.0 \mu \mathrm{m}$ midvalve and 9.7-16.0 $\mu \mathrm{m}$ at the broadest parts: lengthto-width ratio 4.2. Wing projection rather distinct. Alar canals irregularly distributed and smaller than fenestrae, 3.0-3.3 in $10 \mu \mathrm{m}$. Porcae (transapical valve undulations) are irregularly distributed and reach the narrow axial area. The transapical undulations are straight mid-valve, becoming radiate towards the poles. Striae not always visible in LM, about 20-24 in $10 \mu \mathrm{m}$.

Scanning electron microscopy (Figs 36-39): External valve face without ornamentation (spines, granules, ridges). Porcae relatively high and reaching the axial area (Figs 36, 37). Striae mostly biseriate; uniseriate striae also present but then mostly becoming quickly biseriate towards the valve margin (Fig. 38). In a number of striae a third row of areolae are present in a limited part of striae so that it becomes triseriate. Striae composed of round areolae, 65-70 in $10 \mu \mathrm{m}$. Fenestra almost rectangular with slightly rounded angles near the valve face, and with 2-4 thin fenestral bars (Figs $36,37)$. Fenestra are much higher than they are wide. Striation present on the outside of the alar canals on both sides of the fenestrae (Fig. 38). Wings vertically well developed from the valve face, relatively very high near the middle portion of the valve margin and decreasing in height near the apices where they are interrupted leaving a broad space near on pole (the apical pole) (Fig. 38) and a narrower space near the other pole (the base pole) (Fig. 39). Raphe ending near both poles straight and not enlarged (Figs 38, 39). Valve mantle indented and with a similar striation as the valve face (Fig. 39).

Holotype (designated here): Slide NIWR 332/6627 (the valve representing the holotype is here illustrated as Figs 32-33), South African National Diatom Collection, housed at the North-West University, South Africa.

Type locality: Mount Kenya.

Ecology: The taxon was observed in samples from the 

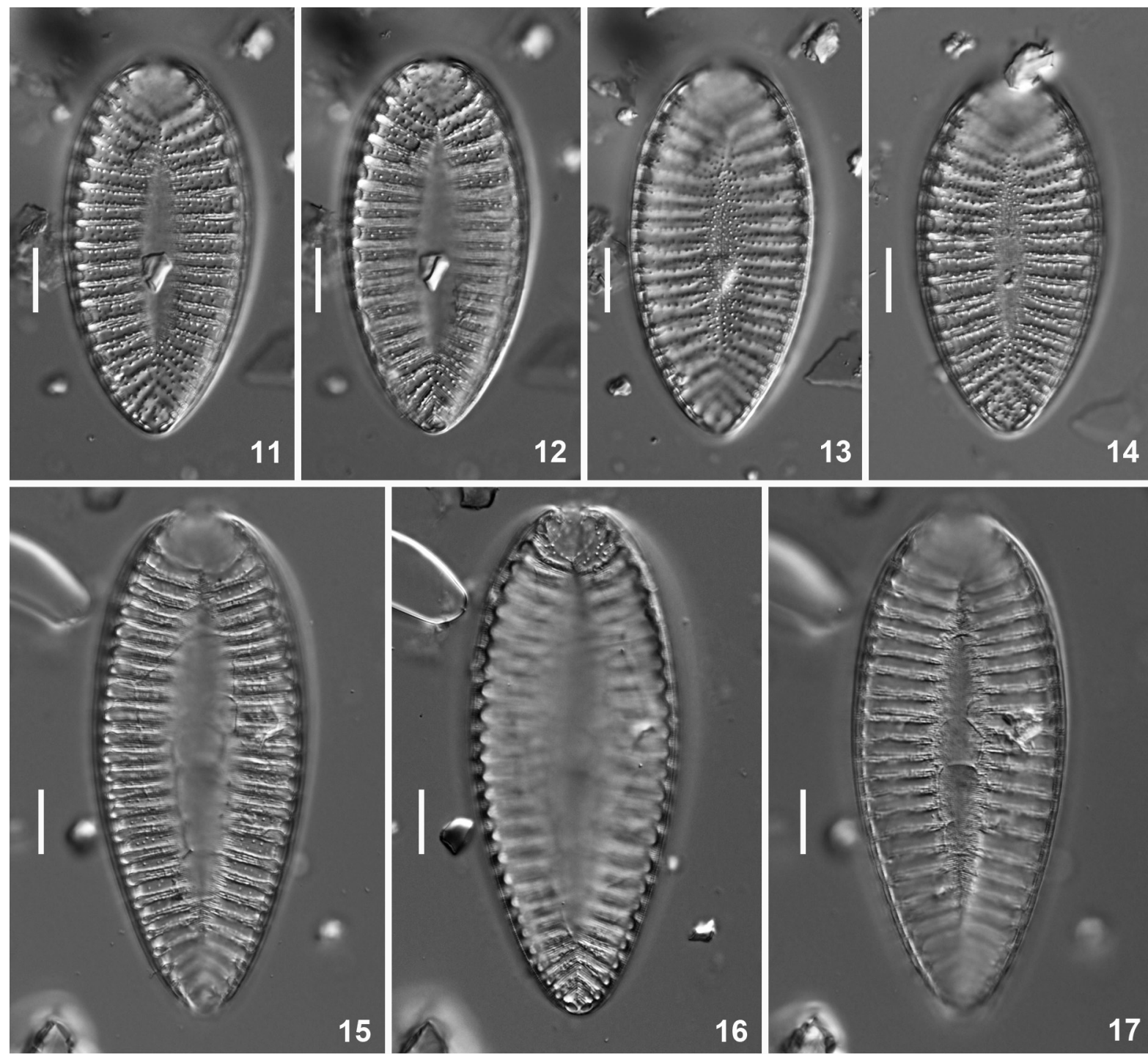

Figs 11-17. Surirella chasei, LM, valves from lectotype slide NWU 07-172: (11-13, 15-17) same valve taken at different foci. Scale bar 10 $\mu \mathrm{m}$.

Alpine zone (4000-4500 m) on Mount Kenya: two samples from Hall Tarn at $4358 \mathrm{~m}$ asl in the Gorges Valley collected by M.J. Coe (CHOLNOKy 1960), and in samples from a sediment core taken in Hausburg Tarn at $4352 \mathrm{~m}$ asl just beneath the Cesar and Joseph glaciers (COCQUYT 2007) sampled by D. Verschuren. In the samples of Hall Tarn, S. coei occurred sporadically; in the Hausburg Tarn sediment record it was common. This points to an alpine ecology of this species: high elevation, low water temperature and conductivity, and oligotrophic water conditions.

Distribution: Mount Kenya, Kenya. Up to now no other records from other high mountains in East Africa such as the Rwenzori Mountains and high mountains in the Virunga National Park.

Remarks: The valves observed in Hausburg Tarn (CoCQuYT 2007) are somewhat smaller than given by
Cholnoky (1960): length 48.0-75.0 $\mu \mathrm{m}$ versus 31.8$42.0 \mu \mathrm{m}$. Cholnoky (1960) discussed the differences beween Surirella coei and two closely related taxa, $S$. linearis f. constricta (EHRENBERG) GRUNOw and Surirella sublinearis HustedT. The valves and the alar canals of $S$. linearis f. constricta are broader; the valves of Surirella sublinearis are also broader, larger and more robust. As mentioned by CocQuYT (2007) a first investigation of the type slide of S. linearis W. Sмiтн (slide BM 2321 b, unpublished data) showed that the valves of this taxon are indeed larger and have less alar canals in $10 \mu \mathrm{m}$ : width of $18.1-24.0 \mu \mathrm{m}$ and 1.8-2.2 alar canals in $10 \mu \mathrm{m}$ compared to a width of 8.0-14.0 $\mu \mathrm{m}$ mid-valve and 9.7-16.0 on the broadest parts of the valve, and 3.0-3.2 alar canals in $10 \mu \mathrm{m}$ in Surirella coei. However, these data on the type of Surirella linearis do not match those listed in several literature resources: length $20.0-125.0 \mu \mathrm{m}$, width 9.0-25.0 $\mu \mathrm{m}, 2.0-3.0$ alar canals in $10 \mu \mathrm{m}$ (Hustedt in 

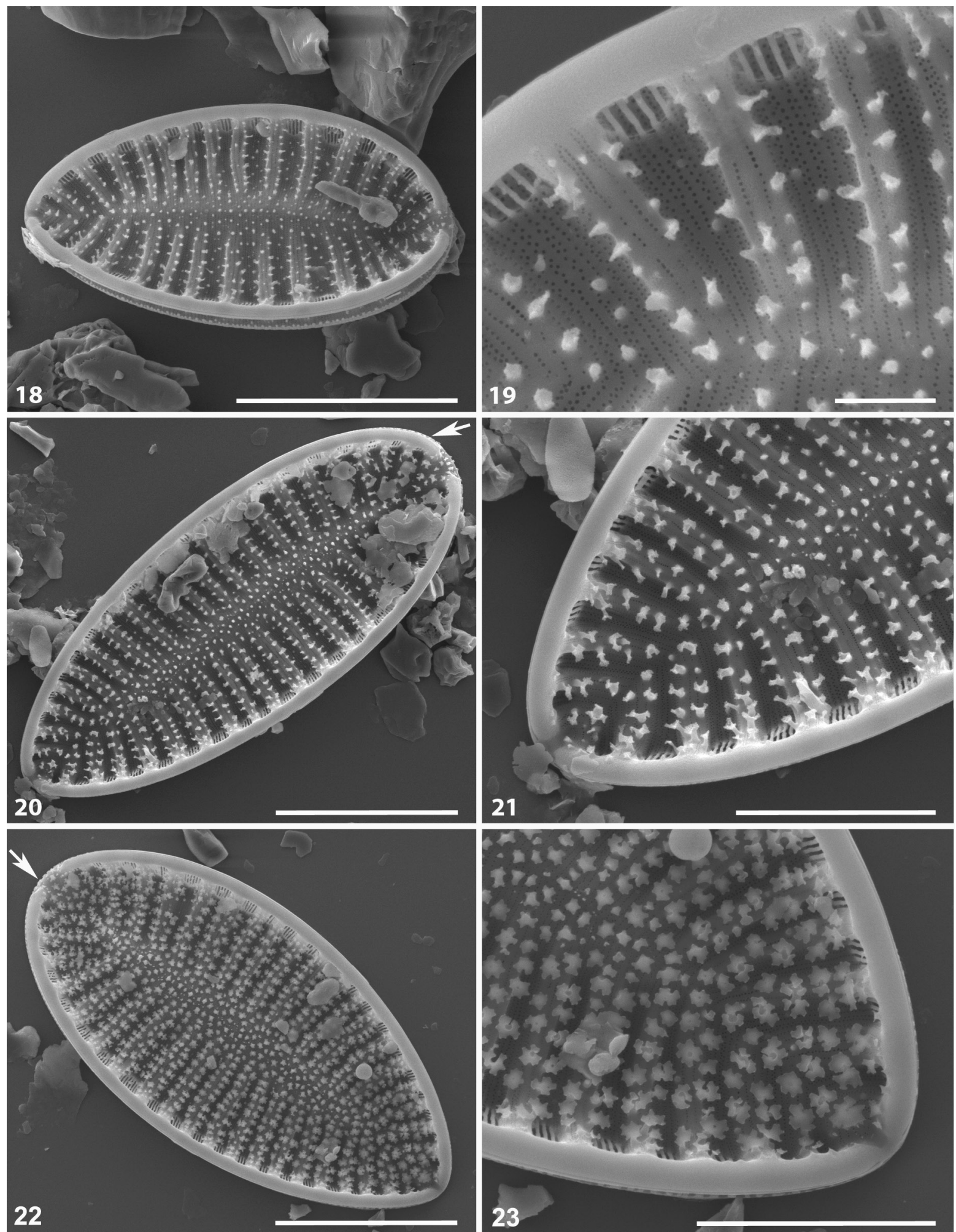

Figs 18-23. Surirella chasei, SEM, type material from sample CH 4: exterior view of valve showing the valve ornamentations, the fenestrae with fenestral bars and the transapical valve undulations; small blunt teeth present near the apical pole at the junction of the valve face and the valve mantle (arrow). Scale bar $20 \mu \mathrm{m}(18,20,22), 10 \mu \mathrm{m}(21,23), 2 \mu \mathrm{m}(19)$.

Huber-Pestalozzi 1942); length 20.0-120.0 $\mu \mathrm{m}$, width: 9.0-25.0 $\mu \mathrm{m}, 2.0-3.0$ alar canals in $10 \mu \mathrm{m}$ (KRAMMer \& LANGe-Bertalot 1988); length 14.0-57.0 $\mu \mathrm{m}$, width $12.0-20.0 \mu \mathrm{m}$ and $2.7-3.5$ alar canals in $10 \mu \mathrm{m}$ (COCQUYT 2007). The constriction of the valve margins is not a differentiating character in Surirella (CocQuYT 2007a), meaning that $S$. linearis f. constricta should be included in the valve variability of $S$. linearis. Most of the observed Surirella coei valves were slightly constricted. We can state with some certainty that Surirella 

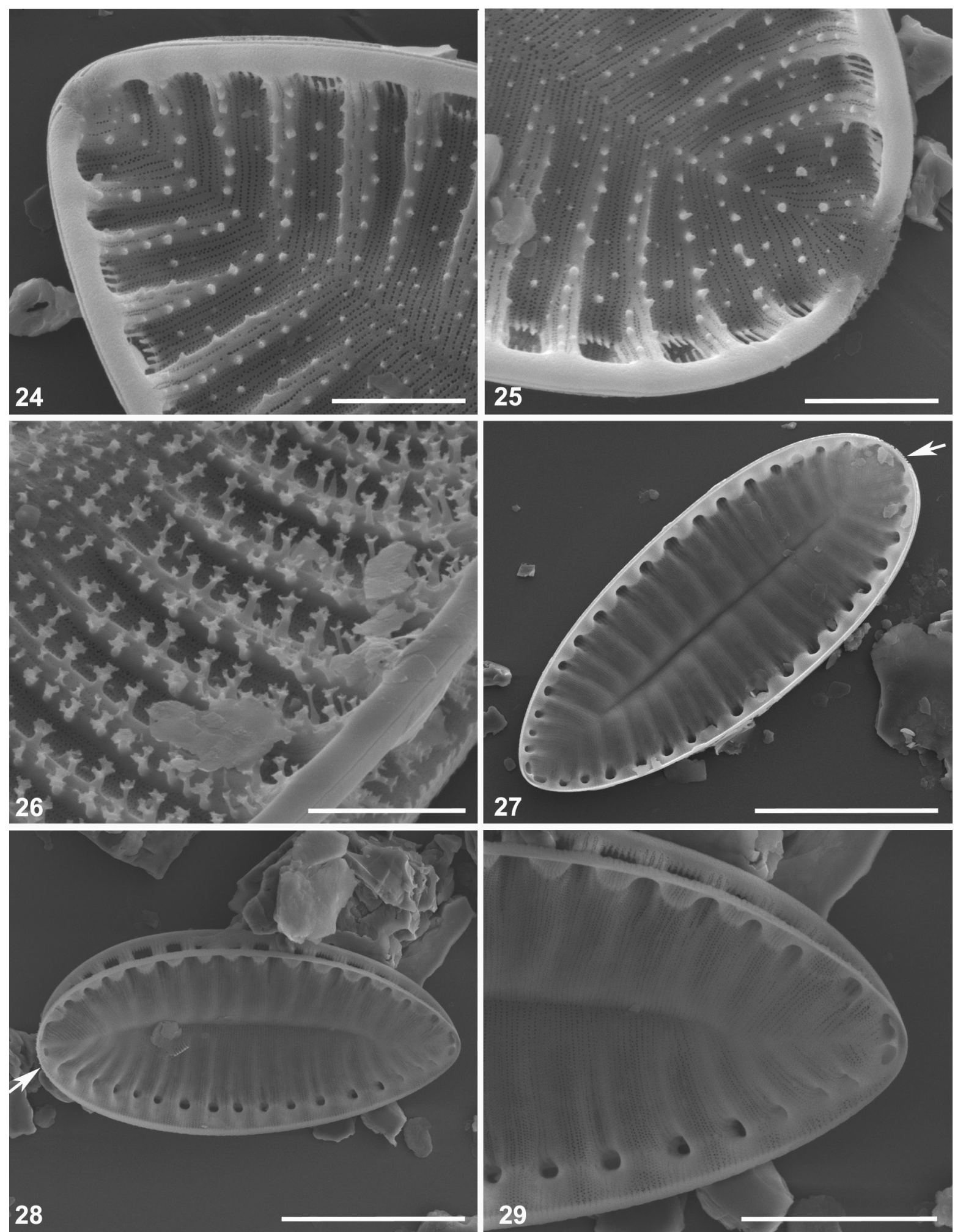

Figs 24-29 Surirella chasei, SEM, type material from sample CH 4: (24-26) exterior view of valve showing the valve ornamentations, (24-25) eroded valve showing the head pole and the raphe endings at the foot pole as well as the uniseriate striae becoming biseriate towards the valve margin, (26) detail of complex silica structures on the top and on both sides of the porcae; (27-29) interior view of valve, note the small blunt teeth near the apical pole at the junction of the valve face and the valve mantle (arrow). Scale bar $20 \mu \mathrm{m}(28), 10 \mu \mathrm{m}(27,29), 5 \mu \mathrm{m}(24,25,26)$. 


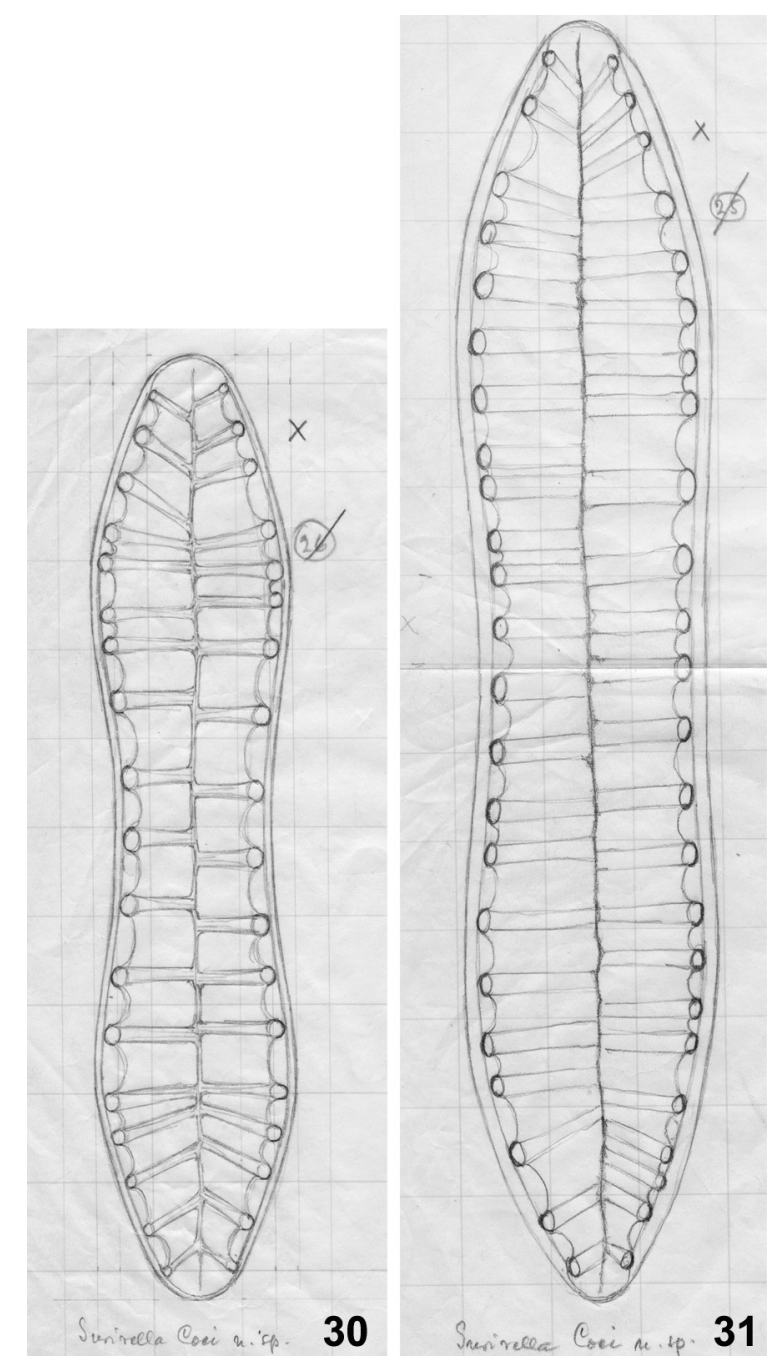

Figs 30-31. Surirella coei, original drawings by Cholnoky, kept at the South African National Diatom Collection, housed at the NorthWest University, South Africa. Each quadrant corresponds with a square of $5 \times 5 \mu \mathrm{m}$

coei and S. linearis are different species. The broadest part of the valves of Surirella sublinearis is significantly wider, $18.0-22.0 \mu \mathrm{m}$, than the 9.7-16 $\mu \mathrm{m}$ width for $S$. coei. The length of the valves is generally larger for $S$. sublinearis $(55.0-75.0 \mu \mathrm{m})$ and more robust than for the valves of $S$. coei $(31.8-75.0 \mu \mathrm{m})$. Although Simonsen (1987) designated a lectotype, we are convinced that no statement can be made regarding the precise identity of Surirella sublinearis, unless an in-depth study of that taxon, is undertaken.

\section{Surirella oliffii CHOLnOKY (Figs 40-58)}

Österreichische botanische Zeitschrift 103: 90, fig. 134, 1956.

Light microscopy (Figs 40-50): Valves slightly heteropolar, linear-elliptical, broadest part near the head pole, becoming gradually narrower towards the foot pole, often slighlty constricted in the middle. Head and foot pole broadly rounded, sometimes slightly acute. Length 75.0-100.0 $\mu \mathrm{m}$, largest width $24.0-30.0 \mu \mathrm{m}$ and $20.0-23.0 \mu \mathrm{m}$ in the constricted part. Wing projection distinct, about $1.7-2.0$ alar canals in $10 \mu \mathrm{m}$; alar canals narrower than the fenestrae. Porcae reaching the narrow linear axial area; parallel to slightly obliquely orientated to the axial area, diagonal in the middle portion of the valve and becoming radiate near the poles. Striae about 20-24 in $10 \mu \mathrm{m}$, not always visible in LM. Generally few tiny spines present in the depressions of the porcae.

Scanning electron microscopy (Figs 51-58): Striae uniseriate near the axial area and becoming bi- to triseriate near the fenestrae, composed of small round areolae (Figs 55, 58). Areolae on the top of the verrucae often rimmed. Fenestral bars about 24 in $10 \mu \mathrm{m}$ (Fig. 52). Small silica cubes and spines scattered only on the top of the transapical valve undulations and on the raphe canal (Figs 51, 52, 55, 56); spines are less abundant than the cubes and can attain about $1 \mu \mathrm{m}$ in length (Figs 53, 54). Raphe endings straight and not enlarged (Figs 53, 54). Mantle strongly indented, and fringed near the raphe canal with $15-20$ teeth in $10 \mu \mathrm{m}$ (Fig. 54). Irregular oval silica plaques present on the valve mantle near the junction with the girdle (Fig. 54). Valvacopula open near one of the poles (Fig. 54).

Lectotype (designated here): [icon] Cholnoky reproduced in CHOLNOKY 1956, fig. 134; here reproduced as Fig. 41. South African National Diatom Collection, housed at the North-West University, South Africa.

Epitype (designated here): Slide NIWR 193/3860 from sample Tugela 285 (the valve representing the epitype is here illustrated as Fig. 46), South African National Diatom Collection, housed at the North-West University, South Africa.

Type locality: Kwa-Zulu Natal, Umgeni River at Albert Falls, Umgeni, South Africa.

Epitype locality: Kwa-Zulu Natal, Umhlalzi River between Eshowe and Melmoth, South Africa.

Ecology: optimum in alkaline waters (CHOLNOKY 1968).

Distribution: South Africa, Swaziland, Chad.

Remarks: In the description of this taxon CHOLNOKY (1956) mentioned that there are no spines or processes present on the valves of Surirella oliffii. However, some years later CHOLNOKY (1962) reported valves ornamented with few tiny spines along the porcae. All valves observed during the present study bore tiny spines but always in a small number and along the junction of the depression and top of the verrucae.

At a first view the four drawings Cholnoky originally made of this taxon (Figs 40-43), of which only three were published (CHOLNOKY 1956, 1960, 1962), seem not to belong to the same taxon, but to three different entities. A comparison of the morphological fea- 

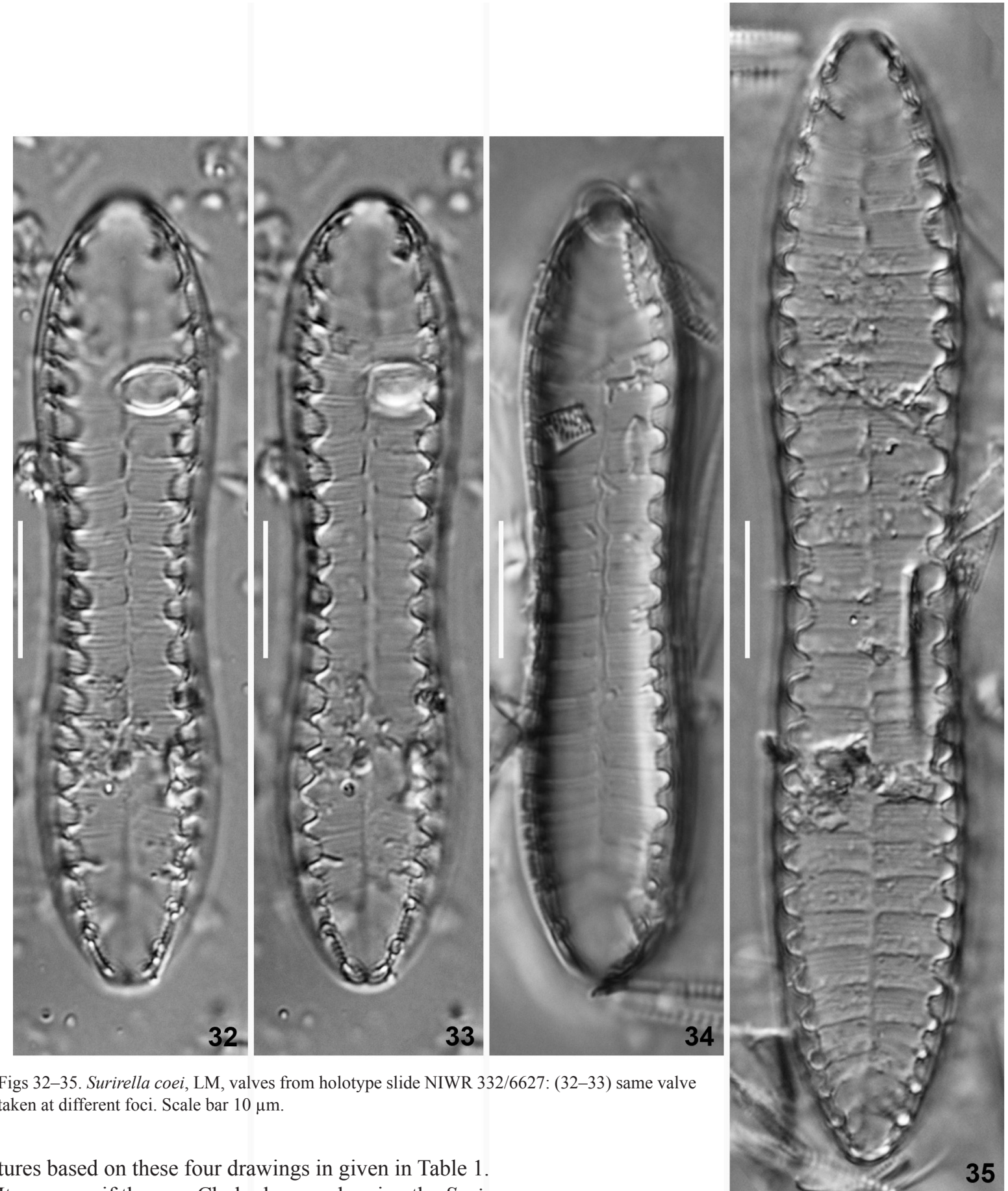

tures based on these four drawings in given in Table 1. It seems as if the way Cholnoky was drawing the Surirella taxa changed over time and that he did not always put the valves in the same focus. The drawing accompanying the description of the type could not be verified as the type slide is missing from the South African National Diatom Collection. Therefore we designated here a epitype (slide NIWR 193/3860 Tugela 285) from a resembling habitat also located in Kwa-Zulu Natal and not too far from the type locality; the original drawing by Cholnoky was designated as the lectotype. Most of the valves in the epitype slide resemble well the original drawing reproduced here in Fig. 42 and as fig. 348 in СHоLNоку (1960c), but also some transition forms to the original drawings from the type locality Umgeni, reproduced here in Figs 40-41, were found

(Figs 46-49). The fourth drawing reproduced her in Fig. 43 differs from the others mainly in the presence of tiny spines. СноLNoкy (1962, p. 337) mentioned that the presence of these tiny spines is not genetically determined and used to be assigned as form punctata. A similar observation was made in $S$. sparsipunctata where the presence or absence of small granules (not spines) is not a good characteristic to determine a taxonomic entity (Cocquyt \& Vyverman 1993).

Cholnoky mentioned already that $S$. oliffii is related to $S$. elgeri Hustedt, to $S$. rudis Hustedt and to $S$. decipiens Hustedt. Surirella oliffii differs from 

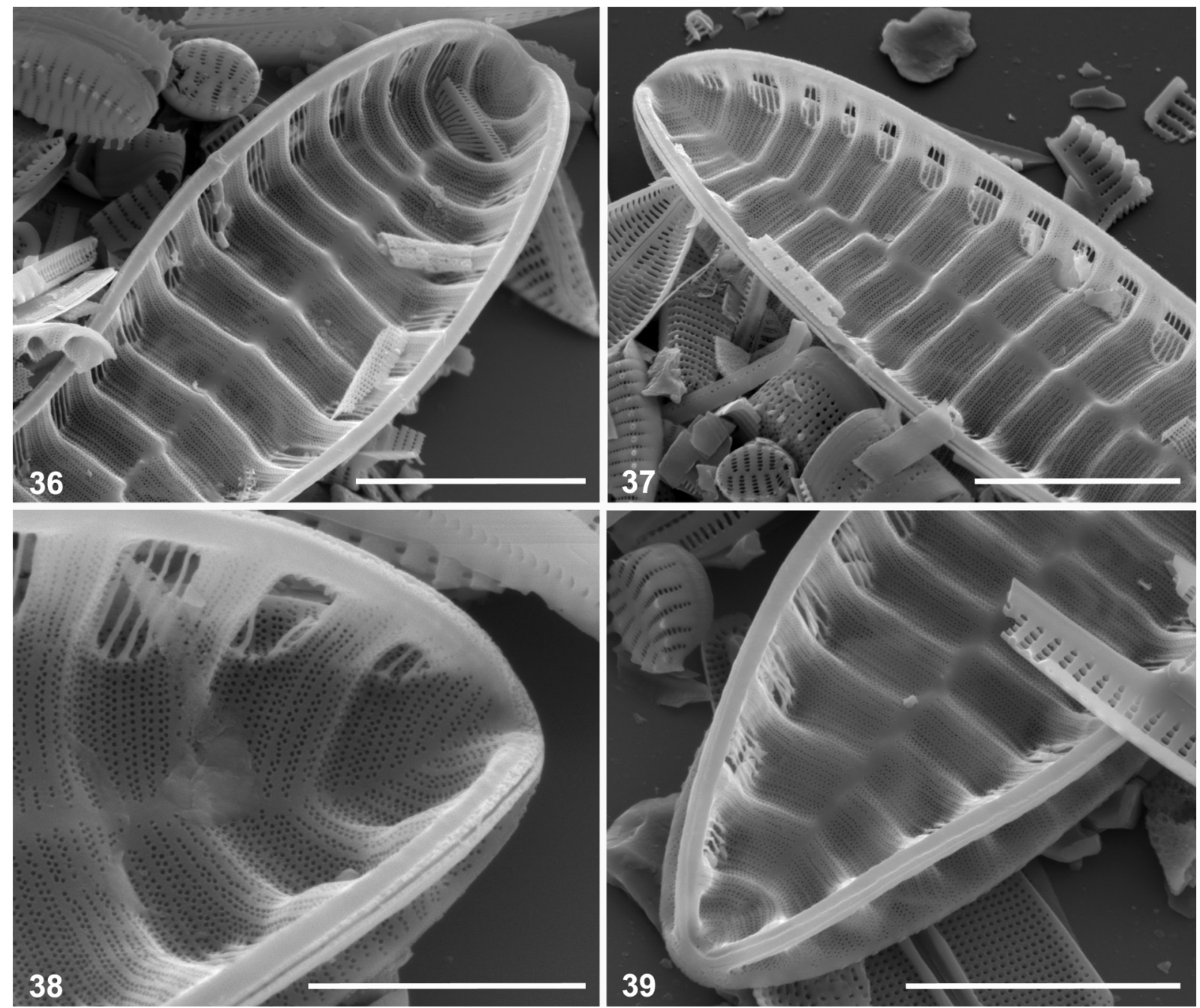

Figs 36-39. Surirella coei, SEM, type material from sample Kenya "A"; exterior view of valve showing the transpical valve undulations and multiseriate striae, the canal raphe and high fenestrae with fenestral bars. Scale bars $10 \mu \mathrm{m}(36-37,39), 5 \mu \mathrm{m}(38)$.

S. elgeri, described from Fagula, Samoa by being much larger and more robust: $75.0-100.0 \mu \mathrm{m}$ long and $24.0-30.0 \mu \mathrm{m}$ broad versus $55.0-73.0 \mu \mathrm{m}$ long and 15.0-19.0 $\mu \mathrm{m}$ broad. Differences between S. oliffii with $S$. rudis, described from Lake Tanganyika, are the mid-valve constriction which is not always a good taxonomic characteristic in Surirella (see CoCQUYT 2000; COCQUYT \& JAHN 2007), and the more ovate-elliptical valve-outline. In his original description CHOLNOKY (1956) mentioned also that the presence of small spines on the valve face of $S$. rudis differentiates it from $S$. oliffii but in 1962 he added the possible presence of spines to his description. Surirella decipiens described from Sulawesi (previously Celebes) is much smaller than S. oliffii (about 50.0-60.0 $\mu \mathrm{m}$ long and 16.0-20.0 $\mu \mathrm{m}$ broad), has a less developed wing structure, and has a characteristic line of spines (Hustedt in HuberPESTALOZZI 1942; BrAMBERGER et al. 2006).

Surirella oliffii is also related to some taxa described from West Africa: S. agonaensis Foged and $S$. bonsaensis Foged (Foged 1966). S. agonaensis has a smaller number of alar canals in $10 \mu \mathrm{m}(1.4-1.6)$ and $S$. bonsaensis is isopolar with a higher number of alar canals in $10 \mu \mathrm{m}$ (2.0-2.4) (COCQUYT \& KUSBER 2010). A table summarising the differences in morphological features is given in COCQUYT \& KUSBER (2010).

Surirella oliffii occurs only rarely in the samples studied. Besides from South Africa and Swaziland, this taxon was also reported from Chad (COMPÈre 1975). For comparison to the South African valves, a valve from material of Chad (slide BR 1595, Lake Chad, north-eastern branch of the delta; collected by Iltis in 1967) is given in Fig. 50. No differences could be observed between these in LM, and the length, width and number of alar canals in $10 \mu \mathrm{m}(79.0 \mu \mathrm{m}, 26.6 \mu \mathrm{m}$ and $25 \mu \mathrm{m}$ and $1.8-1.9$ in $10 \mu \mathrm{m}$ respectively) match Surirella oliffii.

The interrupted distribution of this taxon, South Africa and Chad, can be explained by the lack of studies in similar habitats (alkaline waters) in between these two countries. 

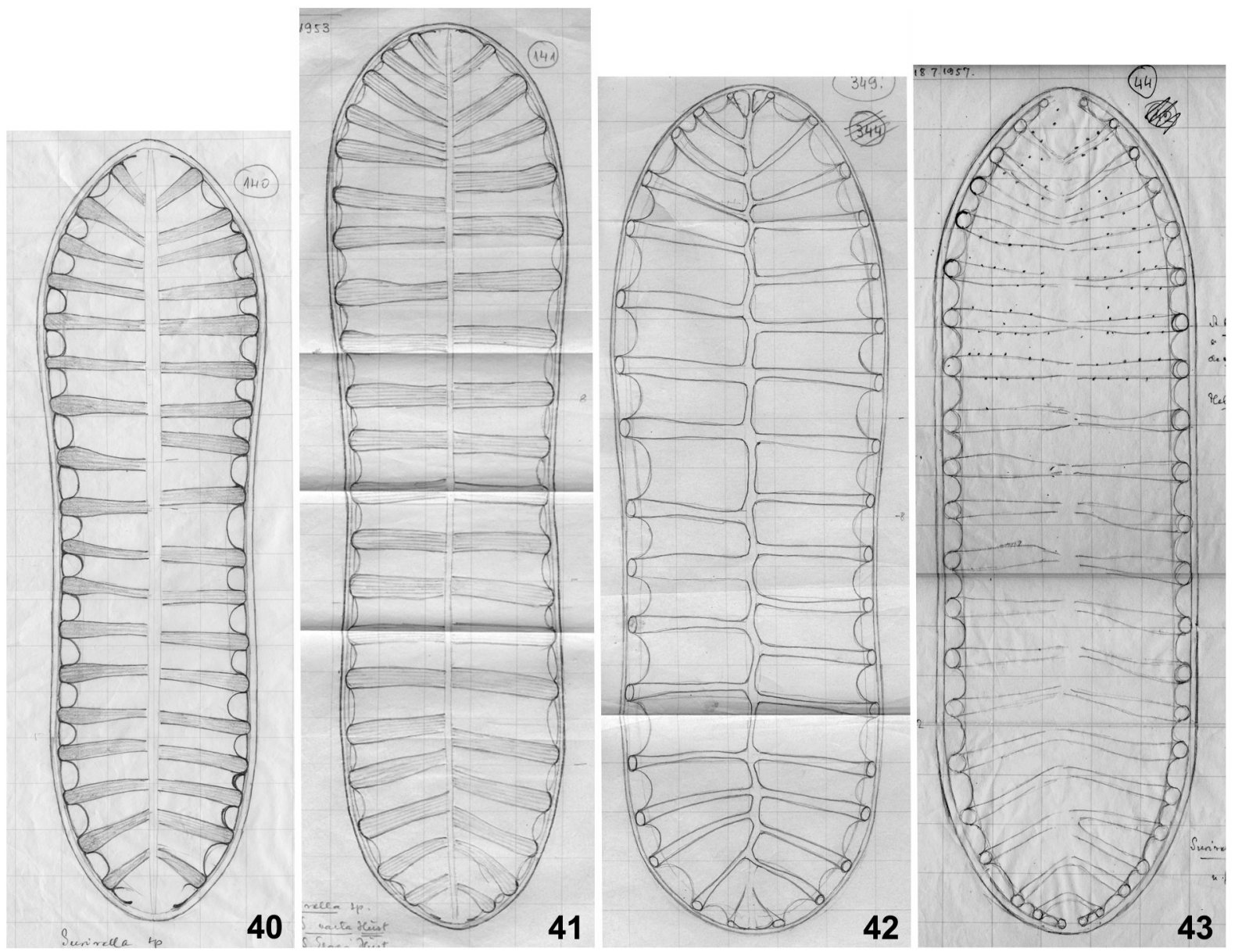

Figs 40-43. Surirella oliffii, original drawings by Cholnoky, kept at the South African National Diatom Collection, North-West University, South Africa. Each quadrant corresponds with a square of $5 \times 5 \mu \mathrm{m}$.

\section{Surirella ostentata ChOLnOKy (Figs 59-64)}

Hydrobiologia 19: 106, 1962.

Synonym: Surirella ovata var. africana CHolnoky, Ber. Deutsch. Bot. Ges. 68: 21-22, fig. 46. 1955.

Light microscopy (Figs 59-62): Valves ovate with a bluntly rounded apical pole and a distinctly sharply elongated foot pole, $8.0-13.0 \mu \mathrm{m}$ long and 5.0-6.4 $\mu \mathrm{m}$ wide. Wings very weakly developed. Alar canals about 8 in $10 \mu \mathrm{m}$. Striation on the valve face indistinct.

Scanning electron microscopy (Figs 63-64): Striae parallel in mid-valve, becoming radiate near the apices (Fig. 64). Striae almost reaching the axial area; irregular silica ridges present in between and parallel to the striae which are replaced by silica granules towards the valve margin (Fig. 63). Axial area narrow and almost linear except near the head pole where it is almost absent. Large conopeum present starting at the raphe canal and lying on the valve surface covering it for about $1 / 4$, and interrupted near the apices (Fig. 63). Valve mantle indented. Internally mostly 3 , sometimes 4 of the uniseriate striae, which are strongly radiate near the head pole, are present in each portula (Fig. 64). Girdle bands not observed.
Lectotype (designated here): Slide NIWR 191/3802 from type material, indicated by CHOLNOKY (1962), Tugela 217 (the valve representing the lectotype is here illustrated as Fig. 62), South African National Diatom Collection, housed at the North-West University, South Africa.

Type locality: canal near Vredendal, splitting from the Olifantsrivier in the mountains, Western Cape, South Africa.

Ecology: slightly alkaline water.

Distribution: South Africa and Swaziland; South Africa, Sierra Leone, Ghana, Ethiopia, Afar and Uganda as S. ovata var. africana.

Remarks: In 1955 CHOLNOKY described this taxon as a variety of $S$. ovata KüTZING from which it differs in its characteristic hyaline valves. Seven years later CHOLNOKY (1962) was convinced that the taxon he described as $S$. ovata var. africana had no relationship with $S$. ovata and he elevated it to species rank under the name Surirella ostentata to avoid a later homonym for $S$. africana LEUdUGER-ForTMOREL (LEUdUGER-ForTMOREL 1898). 

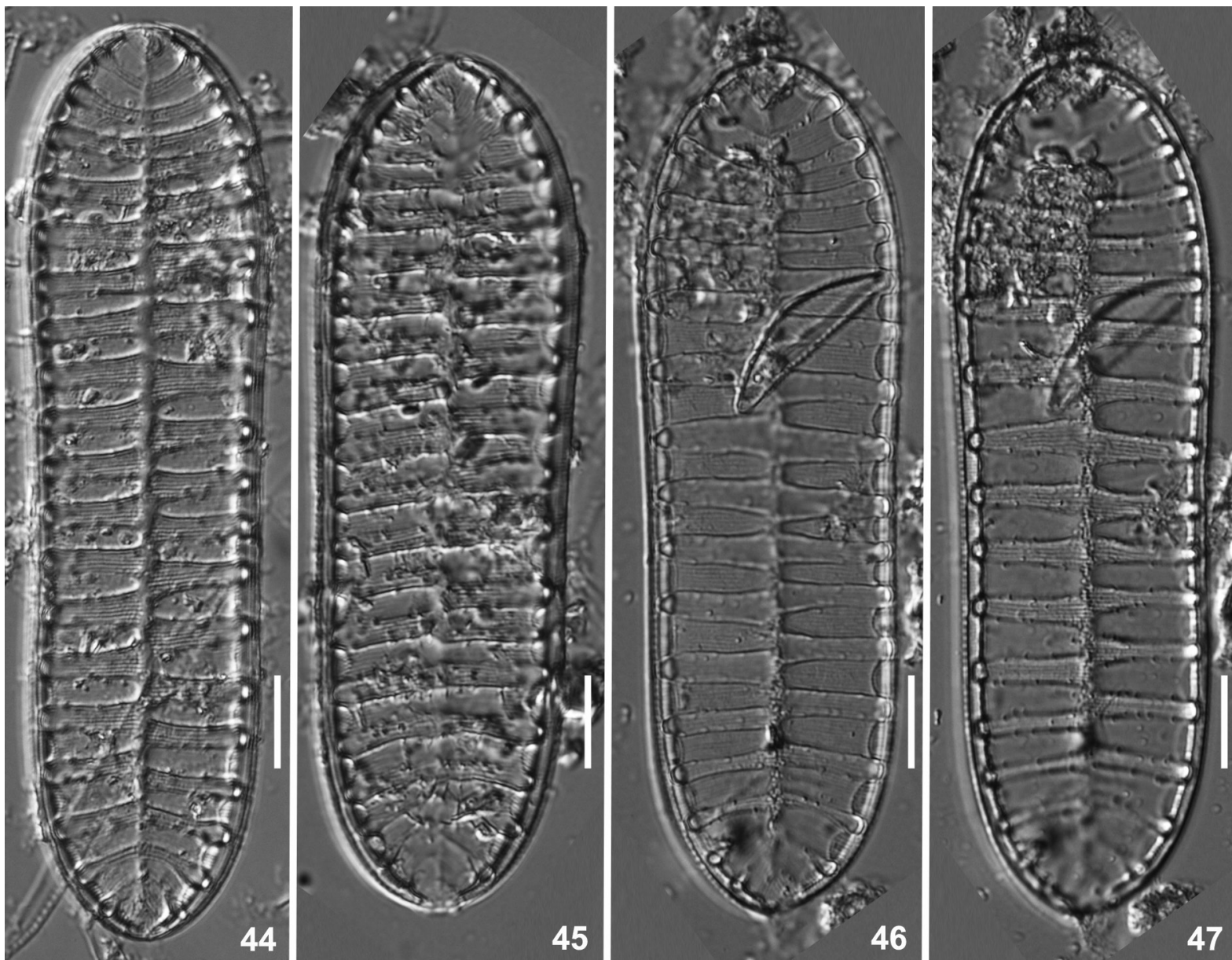

Figs 44-47. Surirella oliffii, LM, valves from epitype slide NIWR 193/3860: (46-47) same valve taken at different foci. Scale bar $10 \mu \mathrm{m}$.

In the type slide only 3 valves could be observed. They all have an oval valve shape as Cholnoky mentioned in his description, in contrast to Cholnoky's original drawing were the foot pole is typically elongated. The sharply elongated foot pole is masked by the well developed conopeum, as in visible in SEM.

This small Surirella species is rather common in samples from Mpumalanga (Eastern Transvaal), in a tributary of the Elands River between Belfast and Machadodorp, South Africa. Valves better resembling the original drawing of Cholnoky were observed in sample NIWR 206/4103 (Figs 65-70). According to the distribution records in the literature, it should be present not only in South Africa but also in East and West Africa. The reports of Surirella ovata var. africana from East Africa are based on Gasse (1986). However this taxon was treated together with the var. ovata and var. pinnata (W. SMITH) BRUN, without illustration and the real identity is to be confirmed. In West Africa MöLDER (1962) found Surirella ovata var. africana rarely $(1 \%)$ in the Kantebge river, with granite and granodiorite bedrock, near Matini in Sierra Leone, and FogED (1966) reported it from a river with clear water in the vicinity of Takoradi in Ghana. Again no drawings are available to confirm the identity of the taxon observed in Sierra Leone and Ghana.

\section{Surirella pseudotenuis CHOLNOKY (Figs 71-78)}

Portugaliae Acta Biologica Ser. B. 4: 226, fig. 120, 1954.

Light microscopy (Figs 71-78): Valves slightly heteropolar, with a rounded apical pole and a acute base pole; length: $22.2-35.0 \mu \mathrm{m}$ and up to $40.0 \mu \mathrm{m}$ for the initial cell (Fig. 78), width: 7.0-9.6 $\mu \mathrm{m}$, length to wide ratio: 2.9. Apical pole not laying in the same plane as the rest of the valve but somewhat curved to the girdle. Alar canals (4.5) 5.5-6.0 in $10 \mu \mathrm{m}$. Wing projection present but not very distinct, alar canals smaller than the fenestrae. About 30 striae in $10 \mu \mathrm{m}$, parallel mid-valve becoming radiate towards the poles. In LM striation only visible on the top of the transapical valve undulations. Transapical undulations shallow, not reaching the axial area. Axial area narrow. Fenestral bars same density as the striae.

Scanning electron microscopy: no valves of $S$. pseudotenuis were observed during SEM investigation.

Lectotype (designated here): Slide NWU 07-138 from material C5 (the valve representing the lectotype 

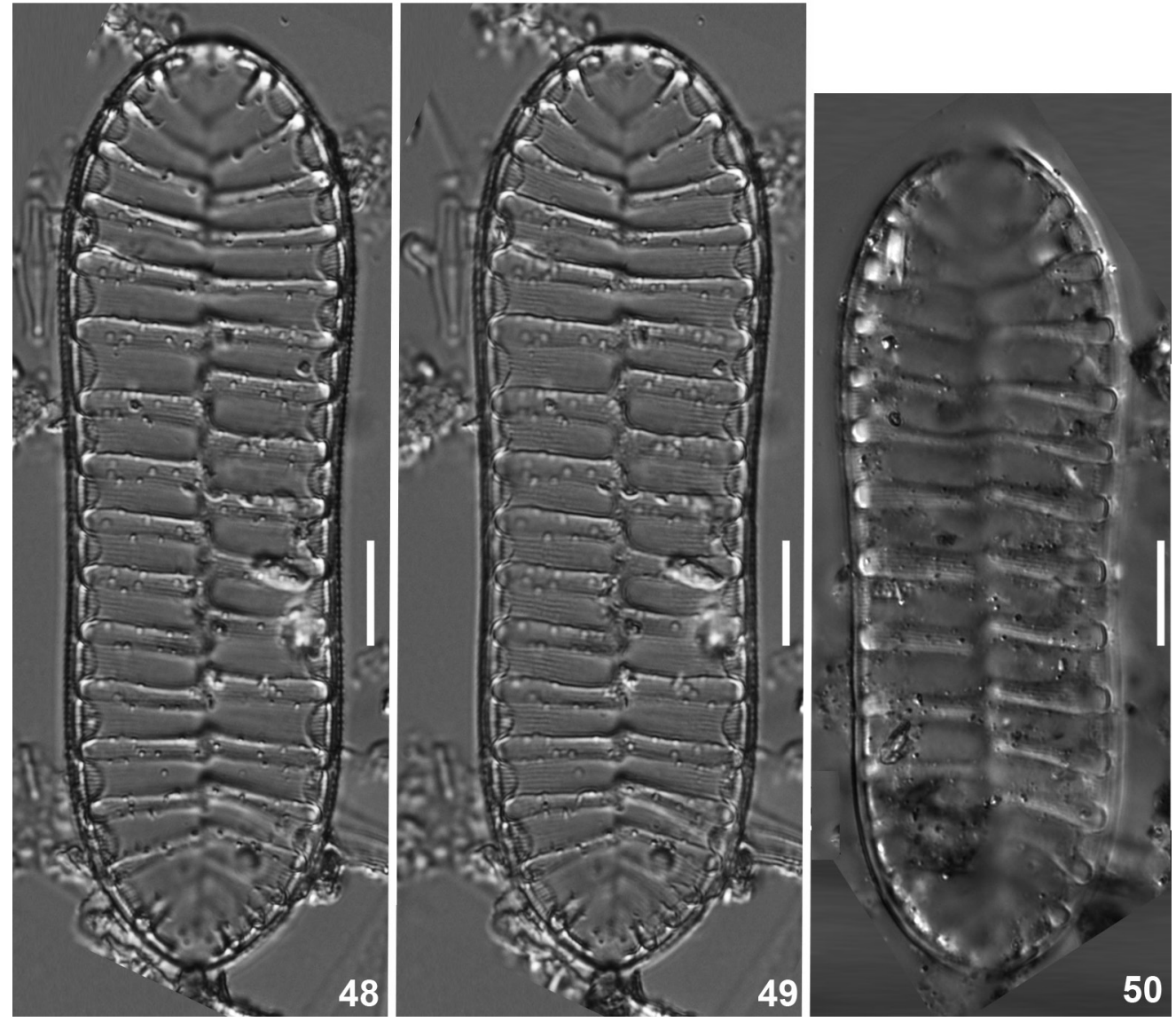

Figs 48-50. Surirella oliffii, LM: (48-49) valve from slide NIWR 193/3860 taken at different foci; (50) valve from slide BR 1595 (Tchad). Scale bar $10 \mu \mathrm{m}$

is here illustrated as Fig. 76), South African National Diatom Collection, housed at the North-West University, South Africa.

Type locality: Gully, south of the road to Vumba, Umatali, South Rhodesia (now Zimbabwe).

Ecology: Found on mosses growing on rocks at the edge of a stream in full sunshine. According to CHOLNOKY (1954) S. pseudotenuis occured together with "moss diatom taxa" typical for small subtropical mesotrophic (to slightly eutrophic) running waters with a $\mathrm{pH}$ around 6 , which are common in the region: dominance of Caloneis chasei CHOLNOKY, and Eunotia praerupta and Nitzschia palea (KütZING) W.SMITH as common species. Rather common taxa in the community were E. tenella and Frustulia saxonica RABENHORST (as F. rhomboides var. saxonica (RABENHORST) De Toni, while Achnanthidium minutissimum (KüTZING) CZARneCKI (as Achnanthes minutissima KützING), Encyonema perpusillum (A. Cleve) D.G. MANN (as Cymbella perspusilla A. Cleve), F. chasei CHOLnOKY, Gomphonema lagenula KüTZING (as G. parvulum var. lagenulum (KÜtZING) Frengueldi), Navicula cincta var. angusta (GRUNOW) A. Cleve (as N. cari var. angusta VAN HeURCK) and Nitzschia ignorata KRASSKE were not uncommon.
Distribution: only reported from Zimbabwe.

Remarks: The observed valve $(22.2 \mu \mathrm{m}$ long and 7.6 $\mu \mathrm{m}$ wide) is smaller than the dimensions given by Cholnoky (1954): 25.0-35.0 $\mu \mathrm{m}$ long and 7.0-9.0 $\mu \mathrm{m}$ wide. On the other hand the number of alar canals in 10 $\mu \mathrm{m}$ is somewhat denser 5.5-6.0 compared to 4.5-5.5 given by CHOLNOKY (1954). СHOLNOKY (1954) remarked that the striae on the valve face are very indistinct even under phase contrast. However the striae on the top of the transapical valve undulations were clearly visible on the lectotype when using differential interference contrast. Differences with the related $S$. tenuis Ant. MAYer (1916) are not only the smaller dimensions of S. pseudotenuis (22.2-35.0 $\mu \mathrm{m}$ long and 7.0-9.0 $\mu \mathrm{m}$ wide versus $22.0-46.0 \mu \mathrm{m}$ and $6.5-10 \mu \mathrm{m})$, but the valves are also less pronouncedly heteropolar, the wing projection is less distinct and the fenestrae are broader than the alar canals.

\section{Surirella pseudothienemannii CHOLNOKY (Figs 79-} 84)

Nova Hedwigia Beiheft 21: 72-73, fig. 184, 185, 1966.

Light microscopy (Figs 79-84): Valves isopolar, linear with conical/tapering not very broadly rounded 

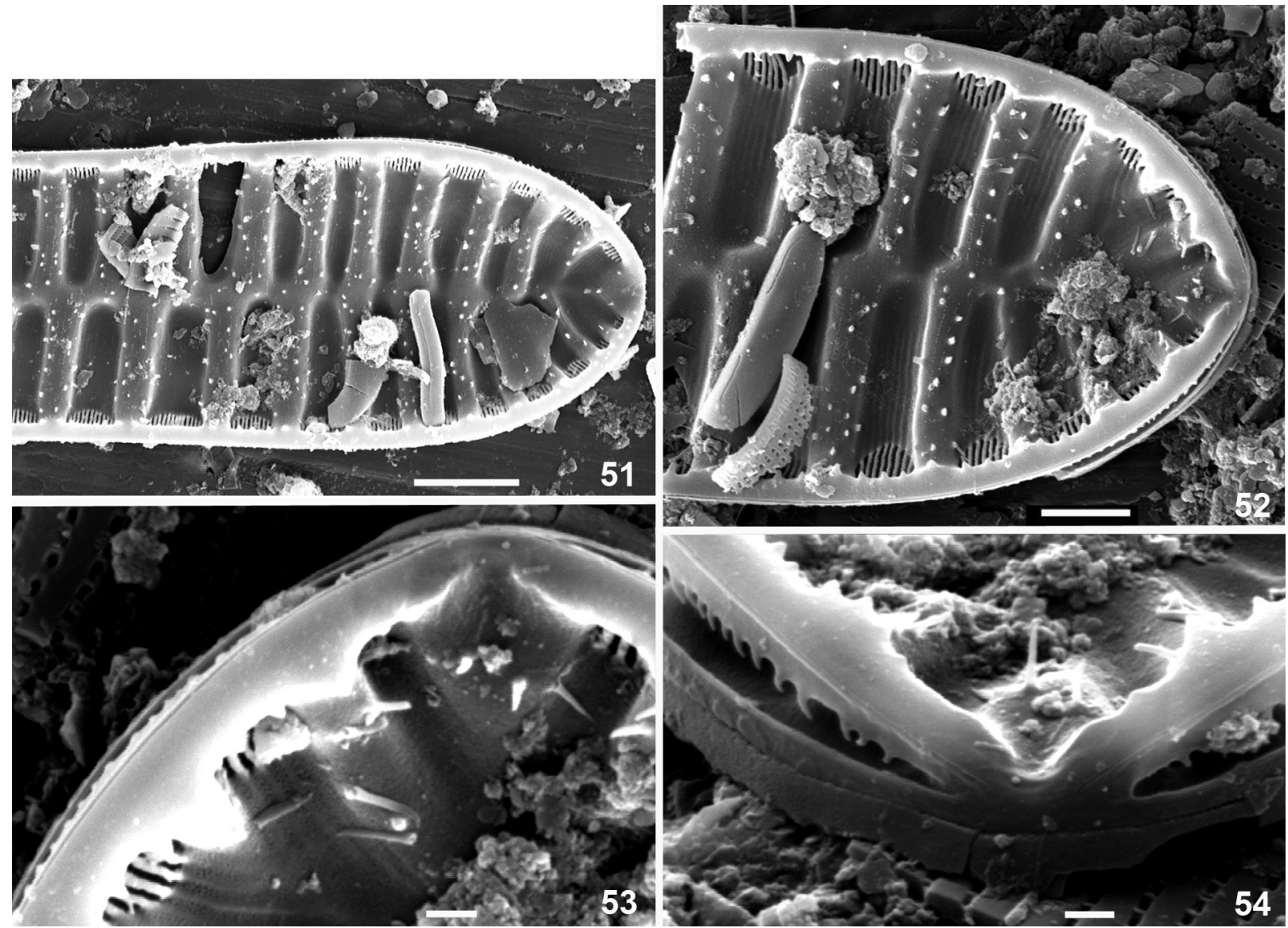

Figs 51-54. Surirella oliffii, SEM from material NIWR 193/3860, outside valve views: (51-52) scattered silica bars on the top of the verrucae and on the raphe canal; (53-54) apical pole with straight raphe endings, (54) silica plaques present on the edge of the indented valve mantle and the side of the valvocopula. Scale bars $10 \mu \mathrm{m}$ (51), $5 \mu \mathrm{m}$ (52), $1 \mu \mathrm{m}(53-54)$.

ends. No constriction mid-valve. Length $90.0-220.0$ $\mu \mathrm{m}$, width $20.0-38.0 \mu \mathrm{m}$. Wing projection narrow, distinct. Transapical valve undulations irregularly distributed on the valve face, parallel mid-valve and strongly radiate near the poles, $1.8-2.8$ in $10 \mu \mathrm{m}$. The depressions of the transapical undulations are much broader than the alar canals. Striae fine, very indistinct.

Scanning electron microscopy: no valves of $S$. pseudotenuis were observed during SEM investigation.

Holotype: Collection numbered S.W. Africa 164, slide NIWR 169/3367 (the valve representing the holotype is here illustrated as Figs 82-83), South African National Diatom Collection, housed at the North-West University.

Type locality: Okavango, in between the indigenous colonies of Tsheye and Shakawe at the limit of South West Africa, British Bechuanaland (now Botswana).

Ecology: freshwater river and swamp.

Distribution: Botswana and South Africa.
Remarks: Closely related to $S$. thienemannii Hustedt (in Huber-Pestalozzi 1942, Bramberger et al. 2006) described from Sumatra and Sulawesi (Indonesia, Asia). Differences between the two taxa can be observed in the shape of the poles, the more strongly radiate alar canals near the poles and the broader axial area in S. peudothienemannii. According to CHOLNOKY (1966) differences can be observed in the wing projection which is very distinct in $S$. pseudothienemann$i i$ while it is narrow and indistinct in $S$. thienemannii. However the reports of $S$. thienemannii in Okavango and South Africa (CHolnoky 1957b, 1960c) have to be checked as at the first view these valves seem to be different from the taxon described from Sulawesi (Hustedt in Huber-Pestalozzi 1942; Bramberger et al. 2006).

It is also related to Surirella engleri O. MüLLER, a common species in Central Africa (COCQUYT \& JAHN 2007a). The main differences between the two taxa are the shape of the poles and the more strongly radiate striae near the poles in S. pseudothienemannii compared to $S$. engleri.

Documentation of African Surirellaceae: Impact for knowledge and science

In this paper we added types, LM and SEM micro- 

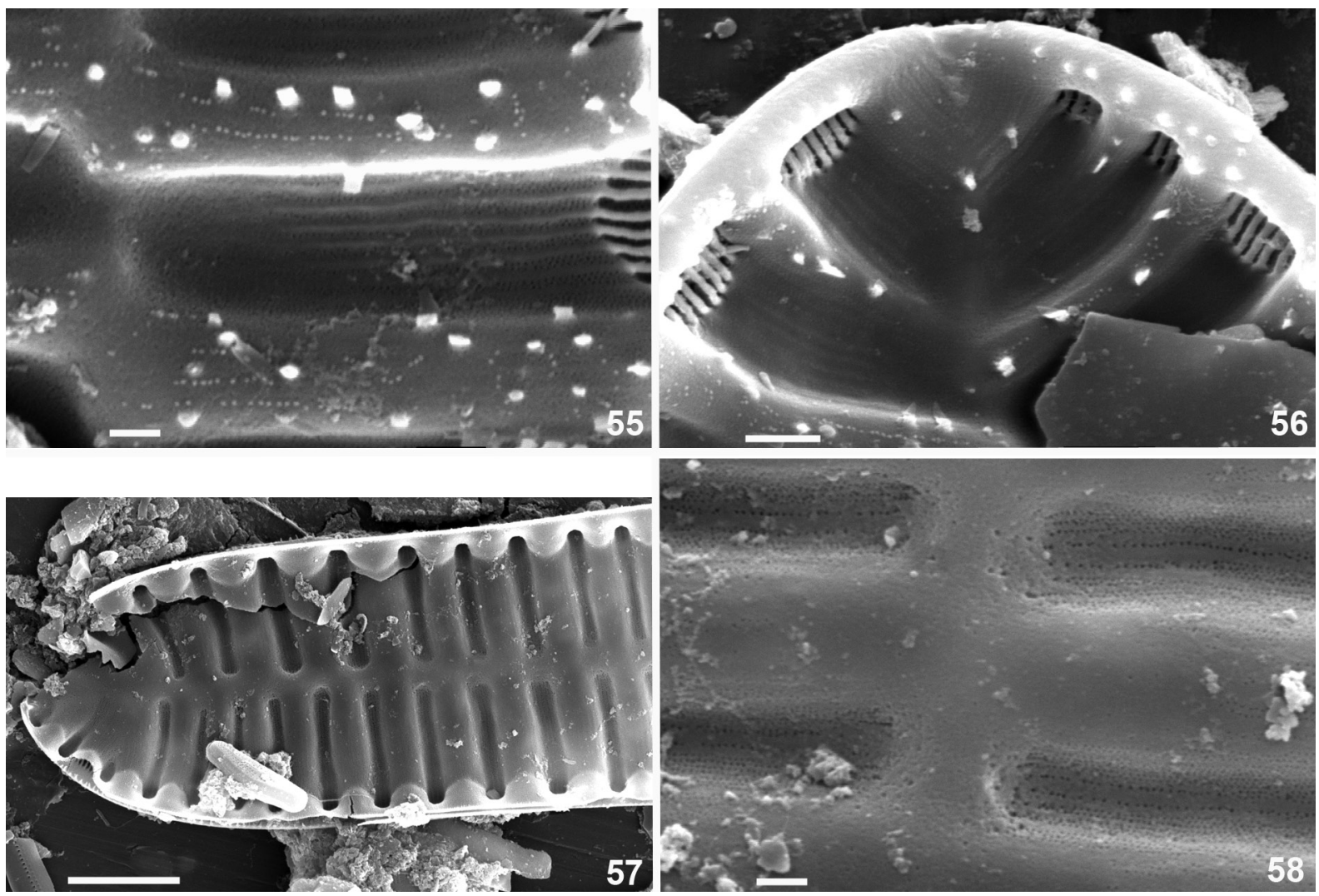

Figs 55-58. Surirella oliffii, SEM from material Tugela 285: (55-56) exterior view of valves with scattered silica bars on the top of the verrucae and on the raphe canal, (57-58) interior view of valves with uniseriate striae near the axial area which become bi- to triseriate towards the raphe canal. Scale bars $10 \mu \mathrm{m}(57), 2 \mu \mathrm{m}(56), 1 \mu \mathrm{m}(55,58)$.

graphs to taxa described by Cholnoky and re-evaluated 7 taxa. To discuss our results on a broader basis we analyzed the series of papers on African Surirellaceae taxa (COCQUYT \& JAHN 2005a, 2007a, b, c, d, 2014; Cocquyt \& Kusber 2010; Cocquyt et al. 2007, 2013 ), collected from the $19^{\text {th }}$ and $20^{\text {th }}$ century and deposited in eight natural history museums in Africa and Europe (B, BM, BR, BRM, C, GENT, NMW, NIWR).

Fig. 85 describes which information was added to the line drawings published in the original literature. For $51 \%$ of the taxa light microscopic images were published and for 30\% scanning electron micrographs were added. Fig. 86 categorizes the outcome of the taxonomic evaluation for taxonomic research. Whereas $12 \%$ of the taxa where investigated without a taxonomical result, $44 \%$ of the taxa received extended documentation, $4 \%$ were validated, $18 \%$ synonymized with accepted taxa, $18 \%$ of the taxa received a new name and or a new rank, and $4 \%$ of the taxa in the investigated material were described as new to science. Nomenclatural types, linked to a taxonomic name, are a key to resolving taxonomic identity. For $16 \%$ of the names no nomenclatural type was found, for $19 \%$ of the names types were already available, for $57 \%$ of the taxa lectotypes were designated, and for some taxa an explanatory epitype was additionally designated (Fig. 87).

\section{Discussion}

In this study the Cholnoky's material of Surirellaceae was reinvestigated by light and, if possible, scanning electron microscopy. The descriptions of the taxa were extended and the taxonomic status of taxa described as new by Cholnoky was confirmed.

As this is the last article of a series of ten studies on African Surirellaceae taxa (COCQUYT \& JAHN 2005a, 2007a, b, c, d, 2014; CocQuyt \& KusBer 2010; CocQuYT et al. 2007, 2013) dealing with nomenclatural types, we discuss the outcome of the "Pilot project on the digitization of African micro-algae types and typical specimens: the diatom family Surirellaceae". The evaluated taxa have been described by seven authors or teams of authors between the 1830s and 1966. All species were depicted by drawings based on light microscopy studies and for all taxa slides and/or materials were deposited in publicly available collections. In publications dealing with diatom research, drawings were replaced in the mid $20^{\text {th }}$ century by light micrographs and complemented soon after by scanning electron micrographs. For $81 \%$ of the taxa included in our reevaluation up-to-date documentation was added. Making nomenclatural types accessible is an important requisite for taxonomy (Sмiтн 2004). Whereas vascular plants have been in the focus of the African Plant 

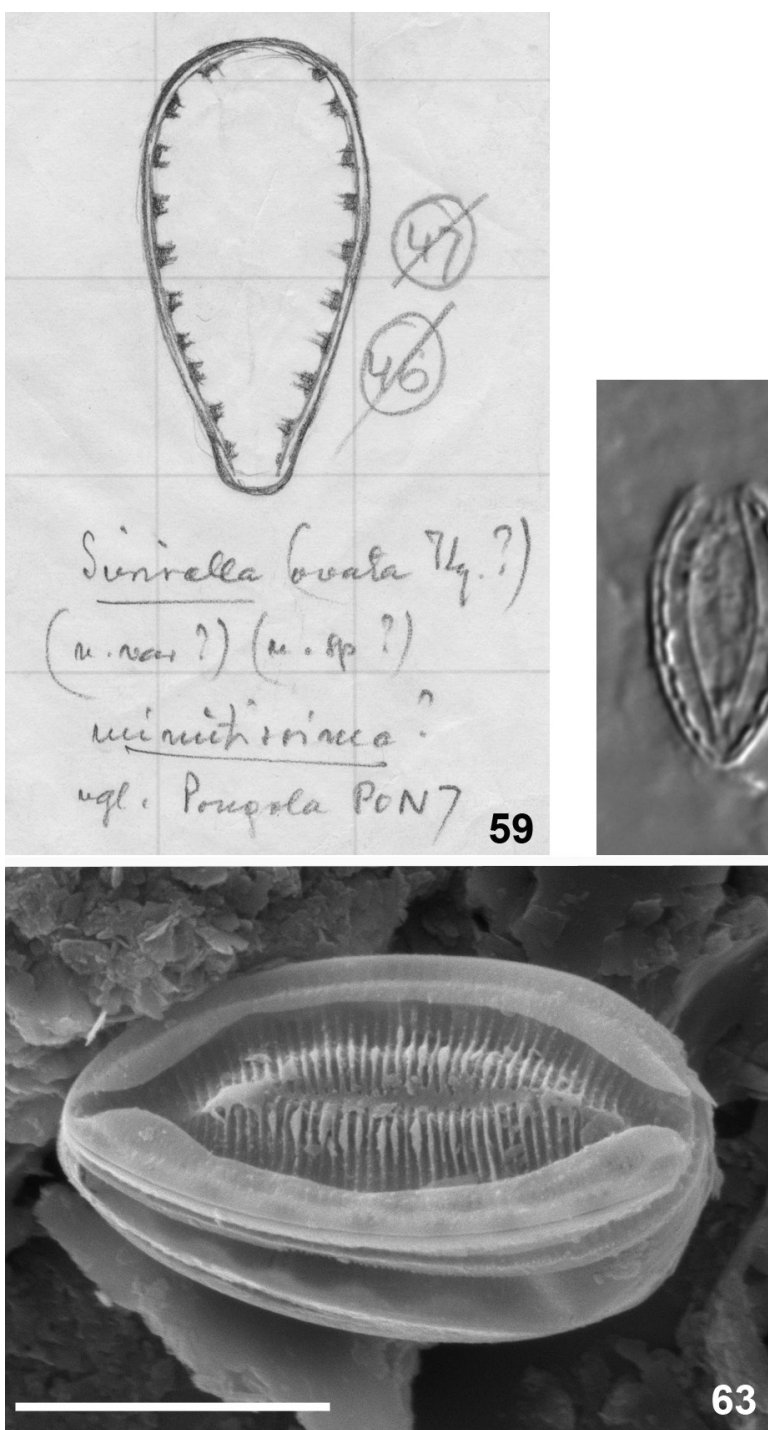
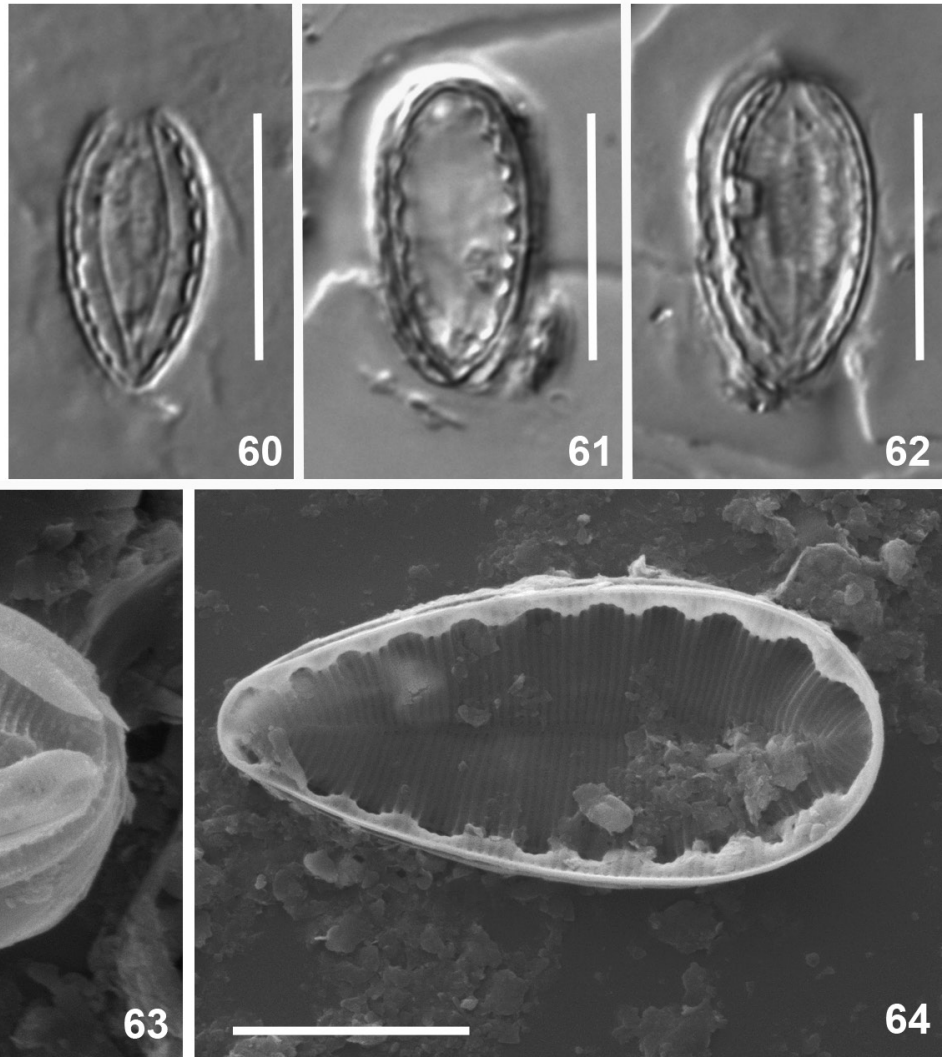

Figs 59-64. Surirella ostentata: (59) original drawing by Cholnoky, kept at the South African National Diatom Collection, North-West University, South Africa, each quadrant corresponds with a square of $5 \times 5 \mu \mathrm{m},(60-62) \mathrm{LM}$, valves from the type slide NIWR 191/3802; (63-64) SEM, valves from type material JO 8, (63) exterior view of valve showing the irregular silica ridges, present in between and parallel to the striae and replaced by silica granules towards the valve margin, and the large conopeum starting at the raphe canal, (64) inside valve view. Scale bars $10 \mu \mathrm{m}(60-62), 5 \mu \mathrm{m}(63,64)$.

Initiative (SMith 2004), KLOPPER et al. (2002) stated that micro-organisms have been severely neglected. One reason might be that digitization of micro algae is not comparable with scans of herbarium sheets because each cell in a mixed sample has to be found, measured and photographed separately. As expected these steps can be very time consuming. In some cases the original material was not available (COCQUYT \& JAHN $2005 \mathrm{~b}, \mathrm{c}$ ), or the labeled species could not be found (CocQuYT et al. 2013), and in one case the cell in a valve moved within a permanent preparation (COCQUYT \& KusBer 2010). Even though diatom material used for descriptions was deposited in collections in most cases strict typification of new taxa was not usual in diatom research before 1958 (JAHN \& KUSBER. 2009), we typified $65 \%$ of the taxa investigated, digitizing the valve representing the respective type. In case where the original material was not available, we epitypified specimens according to the provisions of MCNeILL et al. (2006). This treatment allowed us to link the name to the specimen, which represents the described taxon best.

Compared to the documentation of the Hustedt collection (Simonsen 1987), the Greville collection (WiLliAMS 1988), the Krasske collection (LANGE-BERTALOT et al. 1996) or parts of the Ehrenberg collection (JAHN \& KusBer 2004, 2006), we have chosen a monographic approach for a chosen higher taxon (Surirellaceae). Both approaches are very helpful for studies on diatom taxa, described originally with an outdated documentation. The focus of the first is to make natural history collection specimens available; the focus of the latter is a taxonomic investigation. The latter makes sense, 

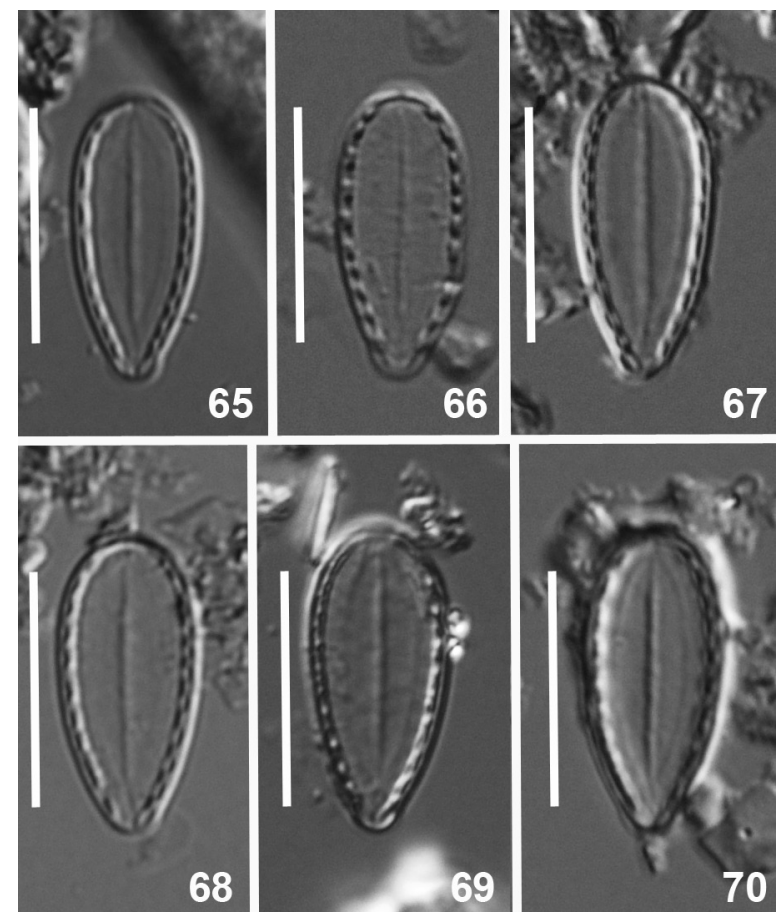

Fig. 65-70. Surirella ostentata (syn. S. ovata var. africana), LM, valves from slide NIWR 206/4103. Scale bar $10 \mu \mathrm{m}$.

Fig. 71-78. Surirella pseudotenuis: (71) original drawing by Cholnoky, kept at the South African National Diatom Collection, housed at the North-West University, South Africa. Each quadrant corresponds with a square of $5 \times 5 \mu \mathrm{m} ;(72-78) \mathrm{LM}$, valves from slide NWU 07-138 made from material from sample C 5. Scale bar $5 \mu \mathrm{m}$.
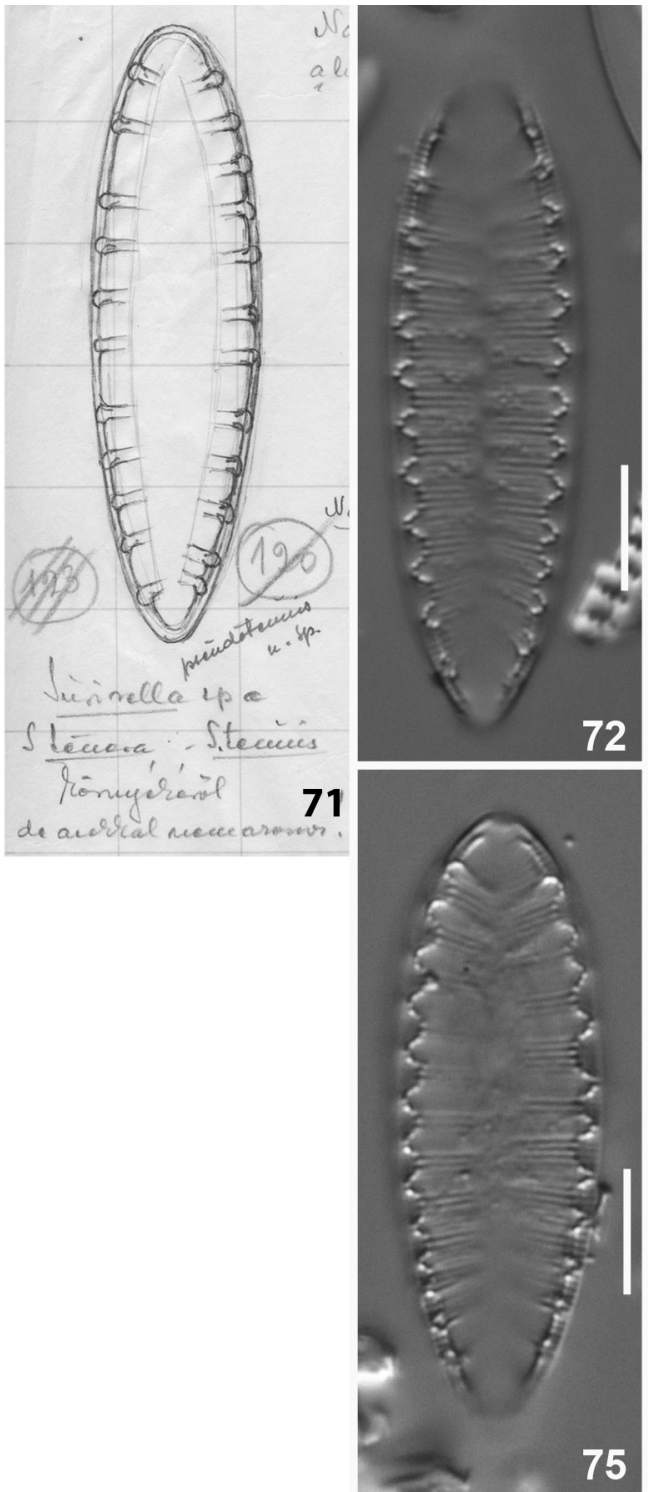
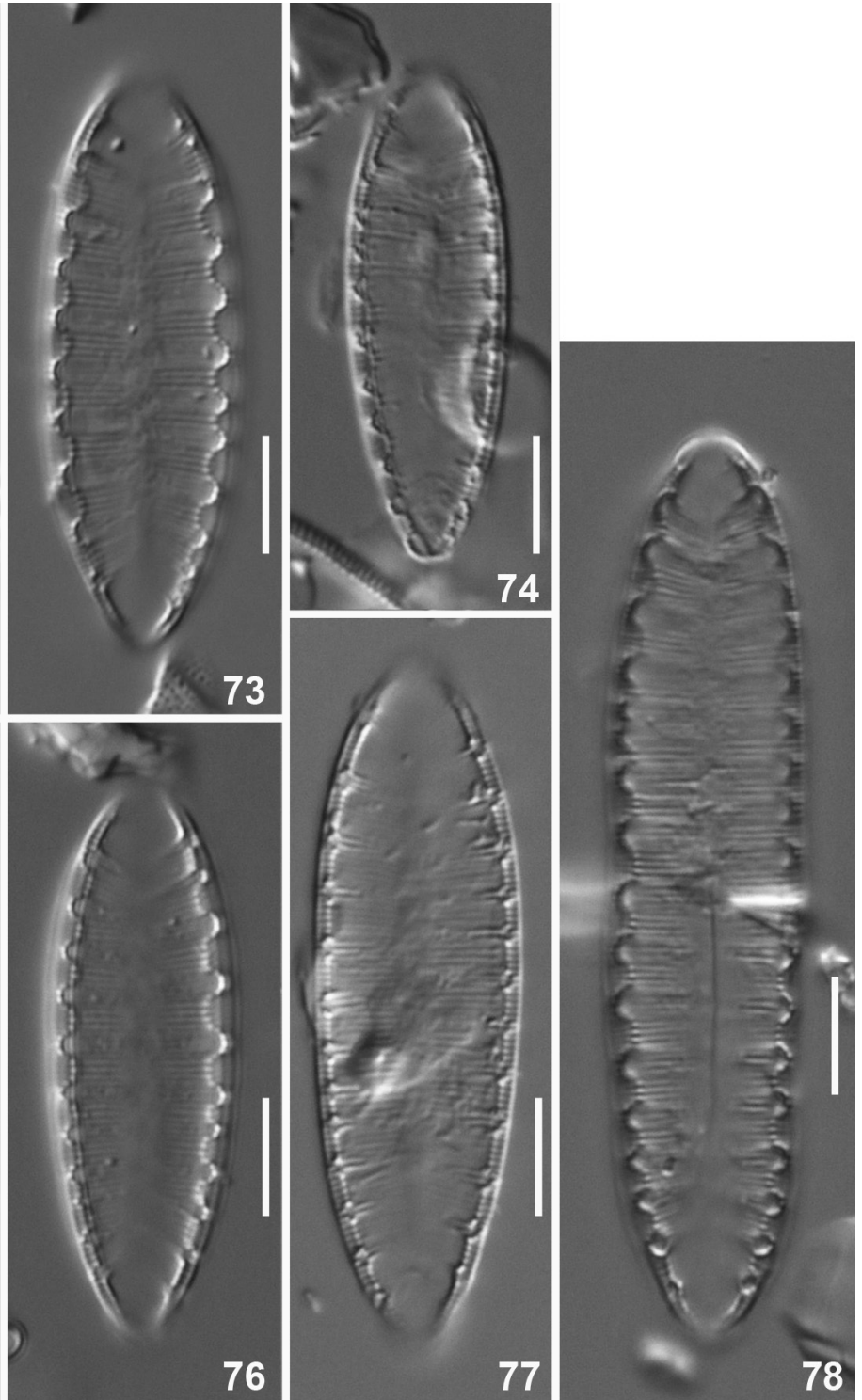


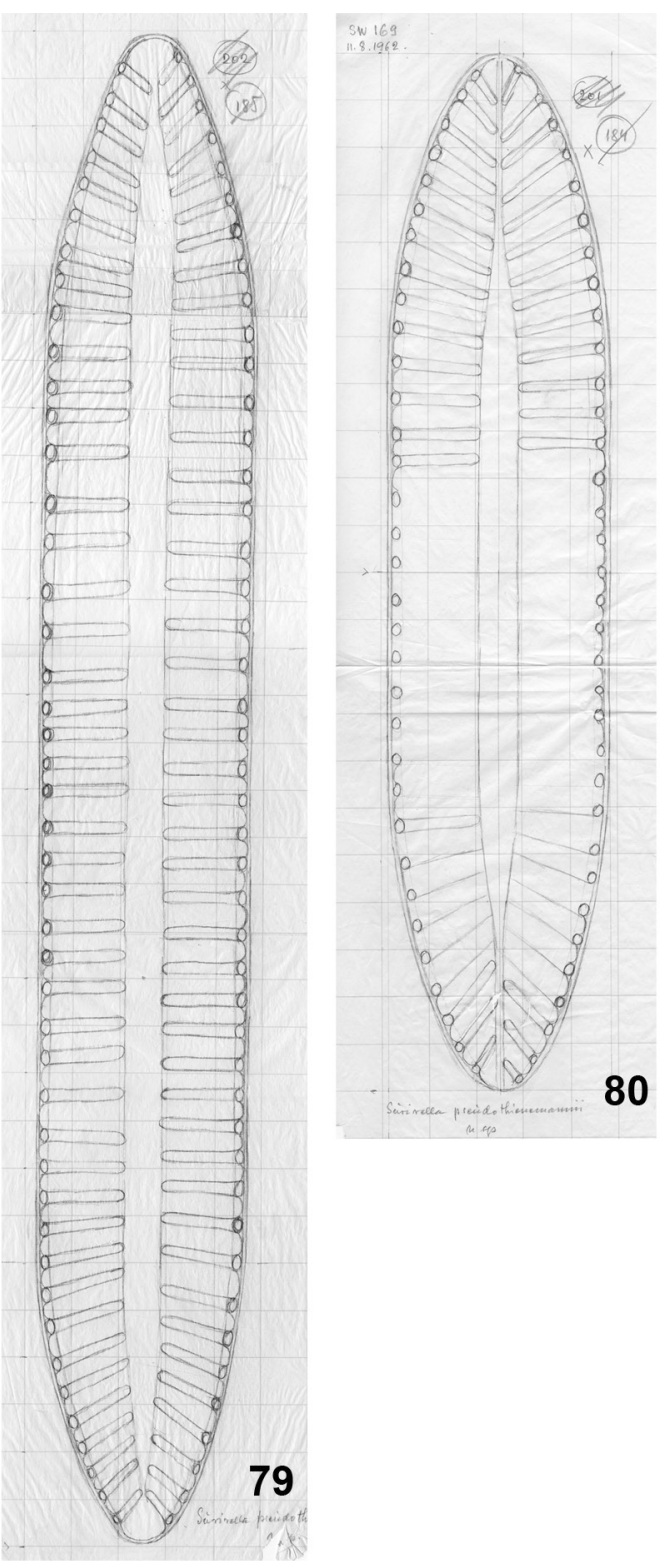

Fig. 79-80. Surirella pseudothienemannii, original drawings by Cholnoky, kept at the South African National Diatom Collection, housed at the North-West University, South Africa. Each quadrant corresponds with a square of $5 \times 5 \mu \mathrm{m}$.

if the material is to be completely taxonomic assessed, especially when no types were designated and the actual identity of the taxon is in doubt. This approach generates the best added value but goes far beyond the scope of a digitization project. In the course of our ten studies, $4 \%$ of the taxa have been validated, $18 \%$ have been synonymized and $18 \%$ have been recombined. Two taxa from historic material proved to be new to science. Our findings emphasise that both deposition of material in publicly available collections as well as re-evaluation of these materials and availability of the results are essential for future research. for funding the "Pilot project on the digitization of African microalgae types and typical specimens: the diatom family Surirellaceae". J.C. Taylor is the recipient of South African National Research Foundation (NRF) incentive funding. Any opinions, findings and conclusions or recommendations expressed in this material are those of the author(s) and therefore the NRF does not accept any liability in regard thereto.

\section{REFERENCES}

Bramberger, A.J.; Hamilton, P.B.; Hehanussa, P.E.; Hinz, F. \& HAFFNER, G.D. (2006): A review of taxa within the genus Surirella from the Malili Lakes, Sulawesi Island, Indonesia, with descriptions of 11 new taxa.Diatom Research 21: 1 - 56.

Brassac, N.M.; Torgan, L.C. \& Ludwig, T.A.V. (2003): Transfer of Surirella schweickerdtii to the genus Stenopterobia. - Diatom Research 18: 185-190.

Cholnoky, B.J. (1954a): Diatomeen aus Süd-Rhodesien. Portugaliae Acta Biologica ser. B 4: 197-228 + 5 pl.

Cholnoky, B.J. (1955): Diatomeen aus salzhaltigen Binnengewässern der westlichen Kaap-Provinz in Südafrika. - Berichte der Deutschen Botanischen Gesellschaft 68: 11-23.

Cholnoky, B.J. (1956): Neue und seltene Diatomeen aus Afrika. II. Diatomeen aus dem Tugela-Gebiete in Natal.- Österreichische Botanische Zeitschrift 103: 53-97.

Cholnoky, B.J. (1957): Neue und seltene Diatomeen aus Afrika. III. Diatomeen aus dem Tugela-Flusssystem, hauptsächlich aus den Drakensbergen in Natal. - Österreichische Botanische Zeitschrift 104: 25-99.

Cholnoky, B.J. (1958): Beiträge zur Kenntnis der Südafrikanischen Diatomeenflora II. Einiger Gewässer im Waterberg-Gebiet, Transvaal. - Portugaliae Acta Biologica Ser. B. 6: 99-160.

Cholnoky, B.J. (1960a): Diatomeen aus einem Teiche am Mt. Kenya im Mittelafrika. Österreichische Botanische Zeitschrift 107: 351-365.

Cholnoky, B.J. (1960b): Beiträge zur Kenntnis der Ökologie der Diatomeen in dem Swartkops-Bache nahe Port Elizabeth (Südost-Kaapland). - Hydrobiologia 16: 229-287.

Cholnoky, B.J. (1960c): Beiträge zur Kenntnis der Diatomeenflora von Natal (Südafrika). - Nova Hewigia 2: $1-128,9$ pls.

Сholnoky, B.J. (1962): Beiträge zur Kenntnis der Ökologie der Diatomeen in Ost-Transvaal - Hydrobiologia 19: 57-119.

Cholnoky, B.J. (1963): Ein Beitrag zur Kenntnis der Diatomeenflora von Holländisch-Neuguinea. - Nova Hedwigia 5: 157-198, Tab. 25-27.

Cholnoky, B.J. (1966): Die Diatomeen im Unterlauf des Okawango-Flusses. - Nova Hedwigia Beiheft 21: $1-102,8$ pls.

Cholnoky, B.J. (1968): Die Ökologie der Diatomeen in Binnengeswässern. - 699 pp., J. Cramer, Lehre.

Cocquyt, C. (1998). Diatoms from the Northern Basin of Lake Tanganyika. - Bibliotheca Diatomologica 39: $1-276$.

Cocquyt, C. (2000): A light and scanning electron microscopic investigation of Surirella brevicostata O. Müller (Bacillariophyceae), an endemic Tropical African diatom. - Systematics and Geography of Plants 70: 

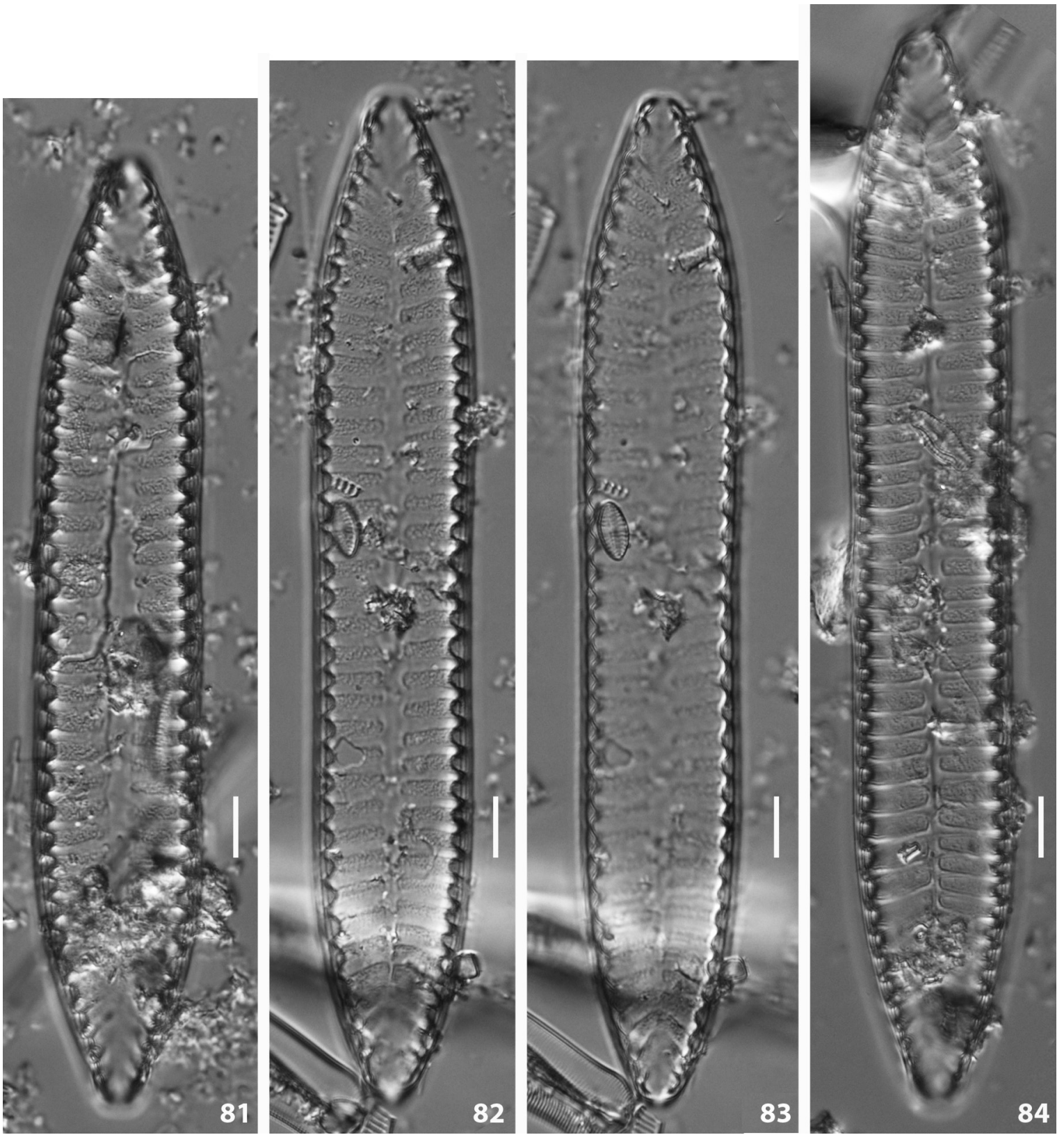

Figs 81-84. Surirella pseudothienemannii, LM, valves from holotype slide NIWR 169/3367: (82-83) same valve taken at different foci. Scale bar $10 \mu \mathrm{m}$.

$245-254$.

CocquYt, C. (2007): Diatom diversity in Hausburg Tarn, a glacial lake on Mount Kenya, East Africa. - Diatom Research 22: 255-285.

Cocquyt, C. \& JAHN, R. (2005a): Rare Surirella taxa (Bacillariophyta) from East Africa described by Otto Müller: typifications, recombinations, new names, annotations and distributions. - Willdenowia 35: 359-371.

CocQuYt, C. \& JAHN, R. (2005b): Surirella capensis Ehrenberg ex Cocquyt \& R.Jahn, spec. nov., a rare and historical diatom species from South Africa. - Cryptogamie, Algologie 26: 149-153.

CocQuYt, C. \& JAHN, R. (2007a): Surirella engleri O.Müller - a study of its types, infraspecific variability and distribution. - Diatom Research 22: 1-16.
Cocquyt, C. \& JAHN, R. (2007b): Surirella fuellebornii (Bacillariophyta) and related taxa: lectotypification and distribution. - Systematics and Geography of Plants 77: 213-228.

Cocquyt, C. \& JAHN, R. (2007c): Taxa related to Surirella ovalis from Tanzania, East Africa: Typification of O. Müller's taxa and description of a new species. Cryptogamie Algologie 28: 107-116.

CocquYt, C. \& JAHN, R. (2007d): Surirella nyassae O. Müller, S. malombae O. Müller, S. chepurnovii Cocquyt \& R. Jahn sp. nov. (Bacillariophyta) - typification and variability of three closely related East African diatoms. - Nova Hedwigia 84: 529-548.

Cocquyt, C. \& Kusber, W.-H. (2010): Reinvestigation of West African Surirellaceae (Bacillariophyta) described by Foged from Ghana. - Nova Hedwigia 91: 


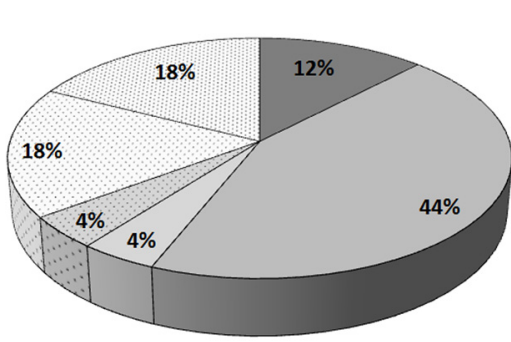

85

ano result

口extended documentation uvalidated

anew taxon

๑syonymised

qnew name or recombinded
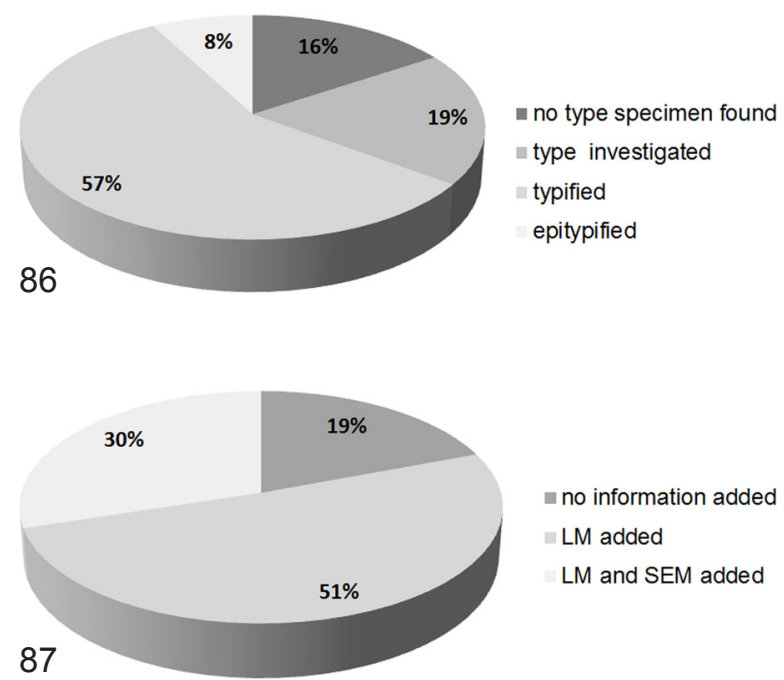

no information added

LM added

LM and SEM added

Fig. 85. Documentation of Surirella and Cymatopleura taxa described from Africa in the $19^{\text {th }}$ and $20^{\text {th }}$ Century $(n=57)$.

Fig. 86. Evaluation of African taxa. Taxonomic impact $(n=57)$.

Fig. 87. Typification of African Surirellaceae names $(n=57)$.

$111-136$.

Cocquyt, C. \& Vyverman, W. (1993): Surirella sparsipunctata Hustedt and S. sparsipunctata var. laevis Hustedt, a light and electron microscopical study. Hydrobiologia 269/270: 97-101.

Cocquyt, C.; Jüttner, I. \& Kusber, W.-H. (2013): Reinvestigation of West African Surirellaceae (Bacillariophyta) described by Woodhead \& Tweed from Sierra Leone (West Africa). - Diatom Research 28: 121-129.

Cocquyt, C.; Taylor, J.C.; Kusber, W.-H.; Archibald, C.; HARDING, W. \& JAHN, R. (2007): Digitizing African Surirellaceae: a pilot study. - In: Kusber, W.-H. \& Jahn, R. (eds): Proceedings of the 1st Central-European Diatom Meeting 2007. - pp. 25-30, Botanic Garden and Botanical Museum Berlin-Dahlem, Freie Universität Berlin, Berlin.

Compère, P. (1975): Algues de la région du Lac Tchad: Diatomophycées. - Cahiers ORSTOM, Série Hydrobiologie 9: 203-290

Foged, N. (1966): Freshwater diatoms from Ghana. - Biologiske Skrifter Det Kongelige Danske Videnskarbernes Selskab 15: 1-169, 25 pls.

Huber-Pestalozzi, G. (1942): Das Phytoplankton des Süsswassers. - In: Thienemann, A. (ed.): Die Binnengewässer, 16(2/2). - pp. 367-549, Schweizerbart'sche Verlag, Stuttgart.

Hustedt, F. (1922): Plate 356. - In: Sснмidt, A. (ed.): Atlas der DiatomaceenKunde. - O.R. Reisland, Leipzig.

JAHN, R. \& KusBer, W.-H. (2004): Algae of the Ehrenberg collection 1. Typification of 32 names of diatom taxa described by C.G. Ehrenberg. - Willdenowia 34: 577-595.

JAHN, R. \& KusBer, W.-H. (2006): Algae of the Ehrenberg collection 3. Typification of seven diatom taxa described by C. G. Ehrenberg predominantly from Greece. - Willdenowia 36 (1 - special issue): $527-$ 535.

JAHN , R. \& KuSBER, W.-H. (2009): A key to diatom nomenclature - Diatom Research 24: 101-111.

Klopper, R.R.; Smith, G.F. \& ChIKuni, A.C. (2002): The Global Taxonomy Initiative in Africa. - Taxon 51: 159-165.

Krammer, K. \& Lange-Bertalot, H. (1988): Bacillariophyceae. 2 . Bacillariaceae, Epithemiaceae, Surirellaceae. - In: Ettl, H.; Gerloff J.; Heynig, H. \& MolLENHAUER, D. (eds) Süsswasserflora von Mitteleuropa 2/2. - 596 pp., Gustav Fisher Verlag, Stuttgart - New York.

Lange-Bertalot, H.; KÜlbs, K.; Lauser, T.; NöRpelSchempr, M. \& Willmann, M. (1996): Diatom taxa by Georg Krasske - Documentation and revision. Iconographia Diatomologica 3: 1-358.

LeUdUger-FortMORel, G. (1898): Diatomées marines de la côte occidentale d'Afrique. - 41 pp., F. Guyon, Saint-Brieuc.

MaYer, A. (1916): Beiträge zur Diatomeenflora Bayerns. I. A. Bacillariales aus dem Fichtelgebirge und angrenzenden Gebieten. B. Bacillariales aus dem bayerischen Walde. - Denkschriften der Bayerischen Botanischen Gesellschaft in Regensburg 13.

McNeill, J.; Barrie, F.R.; Buck, W.R.; Demoulin, V.; GreuTer, W.; Hawksworth, D.L.; Herendeen, P.S.; KnaPP, S.; Marhold, K.; Prado, J.; Reine, W.F.P.H. von; Smith, G.F.; Wiersema, J.H. \& TurLand, N.J. (2012): International Code of Nomenclature for algae, fungi and plants (Melbourne Code) adopted by the Eighteenth International Botanical Congress Melbourne, Australia, July 2011. - 240 pp., Koeltz, Königstein.

MöLDER, K. (1962): Diatomeen aus den Gebirgen Sula und Kangari in Sierra Leone Westafrika. - Bulletin de la commission géologique de Finlande 198: 1-46.

MüLleR, O. (1903): Bacillariaceen aus dem Nyassalande und einigen benachbarten Gebieten. Erste Folge.- Botanische Jahrbücher für Systematik, Pflanzengeschichte und Pflanzengeographie 34: 9-38.

MüLler, O. (1904): Bacillariaceen aus dem Nyassalande und einigen benachbarten Gebieten. Zweite Folge. - Botanische Jahrbücher für Systematik, Pflanzengeschichte und Pflanzengeographie 34: 256-301.

MüLLER, O. (1905): Bacillariaceen aus dem Nyassalande und einigen benachbarten Gebieten. Dritte Folge. - Botanische Jahrbücher für Systematik, Pflanzengeschichte und Pflanzengeographie 36: 137-205.

MüLler, O. (1910): Bacillarien aus dem Nyassalande und einigen benachbarten Gebieten. Vierte Folge. - Botanische Jahrbücher für Systematik, Pflanzengeschichte und Pflanzengeographie 45: 69-122.

Simonsen, R. (1987): Atlas and catalogue of the diatom types of Friedrich Hustedt. - 525 pp., J. Cramer, Berlin \& Stuttgart.

Smith, G.F. (2004): The African Plants Initiative: A big step for continental taxonomy. - Taxon 53: 1023-1025. 
Veselá, J.; Johansen, J.R. \& Potapova, M. (2013): Surirella terryi and S. cruciata: two rare diatoms from North America. - Diatom Research 28: 503-516.

Williams, D.M. (1988): An illustrated catalogue of the type specimens in the Greville diatom herbarium. - Bulletin of the British Museum (Natural History) Botany series 18: $1-148$.
Woodhead, N. \& Tweed, T.D. (1958): Freshwater algae of Sierra Leone. I. New and unusual algae from the Sula Hills. - Hydrobiologia 12: 181-225.

Woodhead, N. \& Tweed, T.D. (1960): Freshwater algae of Sierra Leone 3. The algae of Rokupr and Great Scarcies River. - Revue Algologique 5: 116-150, pls $14-15$.

C Czech Phycological Society (2017)

Received January 8, 2016

Accepted April 6, 2016 